\title{
Spatial-temporal variations and multi-statistical analysis of contaminants in the waters affected by acid mining drainage in Karst area: A case of coal- mining area in Zhijin County
}

\author{
Shichan Qin \\ Guizhou University \\ Xuexian Li \\ Guizhou University \\ Pan Wu ( $\nabla$ pwu@gzu.edu.cn ) \\ Guizhou University \\ Qingguang Li \\ Guizhou University
}

\section{Research Article}

Keywords: Spatial-temporal variations, Multi-statistical analysis, Pearson correlation coefficients, Principal component analysis, Nemerow index method

Posted Date: April 6th, 2021

DOI: https://doi.org/10.21203/rs.3.rs-161814/v1

License: () (i) This work is licensed under a Creative Commons Attribution 4.0 International License.

Read Full License 
Spatial-temporal variations and multi-statistical analysis of contaminants in the waters affected by acid mining drainage in Karst area: A case of coal-mining area in Zhijin County

$$
\text { Shichan Qin }{ }^{1} \text {, Xuexian } \mathrm{Li}^{2,3} \text {, Pan } \mathrm{Wu}^{1,2} \text {, Qingguang } \mathrm{Li}^{1,2}
$$

1. College of Resources and Environmental Engineering, Guizhou University, Guiyang, Guizhou 550025, China

2. Key Laboratory of Karst Environment and Geohazard, Ministry of Education, Guiyang 550025, China

3. College of Agriculture, Guizhou University, Guiyang, Guizhou 550025, China

\begin{abstract}
Due to the adverse effects of coal mining activities in Karst areas, it's necessary to monitor the contaminants, analyze their fate in the transport and identify the sources. Therefore, concentrations of contaminants were measured in both groundwater and surface water samples collected from coal-mining area in Karst, located in Zhijin County, Guizhou Province (China). The analysis of spatial-temporal variations of contaminants indicates that (1) the concentrations of metal elements (except $\mathrm{Ba}$ ) and $\mathrm{SO}_{4}{ }^{2-}$ tend to decrease along the water flow direction while the concentrations of $\mathrm{Ba}$ and nitrate still show an upward trend and (2) the concentrations of metal elements and $\mathrm{SO}_{4}{ }^{2-}$ in Stream1 and Stream3, are higher in wet season than dry season. Further, the results of multi-statistical analysis which combined Pearson correlation coefficients (PCC) with the principal component analysis (PCA), identify five factors for the data structure of contaminants. What's more, the assessment of the water quality was evaluated by Nemerow index method to better understand the status. The results indicate that over $60 \%$ of water samples were divided into Grade IV and Grade V.
\end{abstract}

Keywords: Spatial-temporal variations; Multi-statistical analysis; Pearson correlation coefficients; Principal component analysis; Nemerow index method

\title{
Introduction
}

Assessment and treatment methods of water pollution are of great importance in environmental research since more than two billion people worldwide are confronting with water scarcity issues(Oki et al. 2006). Particularly, pollution of water environment in karst areas has currently become one of the most predominant environmental problems due to (1) the unique and vulnerable dualistic hydrological system which is easy to be polluted and destroyed but hard to be remediated, and (2) the negative impacts of coal mining activities on water environment ( $\mathrm{Li}$ et al. 2018). Also, during coal mining processes, acid mining drainage (AMD) occurs when metal sulfides (such as pyrite, etc.) are exposed to the air and subsequently oxidized by oxygen and water in the medium of microorganisms. The discharge of AMD can induce low 
pH as well as highly concentrated metals (Alpers and Blowes 1994), which are usually non-degradable and significantly toxic to aquatic organisms and human beings (Weimin et al. 2016). Given the severe damage on global watersheds and ecosystems (Blowes et al. 2014; Lottermoser 2010; McCarthy and Terence 2011; Szulczewski 2015), it is vital to control the water pollution and protect ecological environment via identifying the main pollution factors and analyzing their fate in the mining karst area.

Zhijin County in Guizhou Province, China, is a typical karst area with abundant coal resources. By the end of 2013, the identified anthracite deposits have reached 12.9 billion tons, which is the largest anthracite producing area in Guizhou Province. In this mining region, resources in groundwater are abundant, and the entire water supply area is mainly supported by Zhijin River belonging to the Pearl River water system. Here the drinking water mainly comes from karst groundwater, while irrigation water comes from the surface water bodies surrounding farmland. However, many studies have shown that the high-strength and long-term mining of coal mines in Zhijin County has considerable influence on the water bodies(Li et al. 2017; Shi et al. 2016). Moreover, under the unique karst hydrogeological conditions, frequent human activities (e.g., mining activities, agricultural activities and urbanization) have caused multiple pollution to the water bodies with a wide variety of pollutants and complex variations. Therefore, simple mathematical statistical methods are insufficient to conduct a comprehensive and systematic analysis of water pollutants.

Geochemical analysis combined with multiple statistical analysis could better explain the relationship between contaminants(Chen et al. 2016; Cui et al. 2020). One classical approach is to use the Piper diagram to reveal the overall chemical properties of water bodies to analyze the formation of water chemical components(An et al. 2012; Cui et al. 2020). Another widely applied method is the Pearson correlation coefficients (PCC), which can reflect the linear relationship between variables(Abulimiti et al. 2017), and hence qualitatively as well as quantitatively analyze the correlation between pollution factors. Moreover, principal component analysis (PCA) is usually used in source attribution by treating the research area as receptor and subsequently identifying the main components (i.e. possible pollution source) with their degree of influence via dimensionality reduction(Zhuo et al. 2020). It should be noted that PCA is one of the most widely used methods to extract key information for pollutant source research (Gao et al. 2018; Huifen et al. 2020; Yang et al. 2020). In addition, assessment of water quality can more intuitively describe the status of the water environment. Recently, water quality index methods such as Horton index method, Brown index (NSF) method, Nemerow index method, CCME water quality index method, similar index method, PesceWunderlin subjective and objective index method, have been widely employed and practically verified in evaluation of water quality(Lumb et al. 2011; Wu and Li 2014), where the Nemerow index method owns simple structure and strong practicability by highlighting the maximum value as well as involving extreme value (Zheng et al.). 
In this study, the spatial-temporal variations and multivariate statistical analysis of water pollutant in the karst coal mining areas of Zhijin County have been explored. Nemerow index of different water bodies was calculated and water quality was graded by referring to "Groundwater Quality Standard" (GB/T 148482017) and "Surface Water Quality Standard" (GB 3838-2002).

\section{Materials and method}

\section{Site selection}

The study site is located in the Midwest of Guizhou Province, Southwest China which extends from $105^{\circ}$ $39^{\prime} 00^{\prime \prime}$ to $105^{\circ} 46^{\prime} 30^{\prime \prime}$ in the east and from $26^{\circ} 34^{\prime} 30^{\prime \prime}-26^{\circ} 41^{\prime} 45^{\prime \prime}$ in the north (Fig. 1). As one of the most complete karst development areas, Zhijin country is approximately $2868 \mathrm{~km}^{2}$, about $60 \%$ of which is covered by carbonate rocks. From the west to the northeast, the nature of the land has changed from mining to housing. The land use types in the study area are mainly cultivated land, forest land and residential land.

The county has a subtropical monsoon climate, with mean annual temperature $14.1^{\circ} \mathrm{C}$ and mean annual precipitation $1436 \mathrm{~mm}$. Under the control of topography and synclinal structures, the groundwater flows from the southwest to the northeast and eventually converges in Zhijin River valley, which then expose to the surface in the form of karst springs, which is the indispensable drinkingwater supply of Zhijin County. And the irrigation system is composed mainly of surface water. 


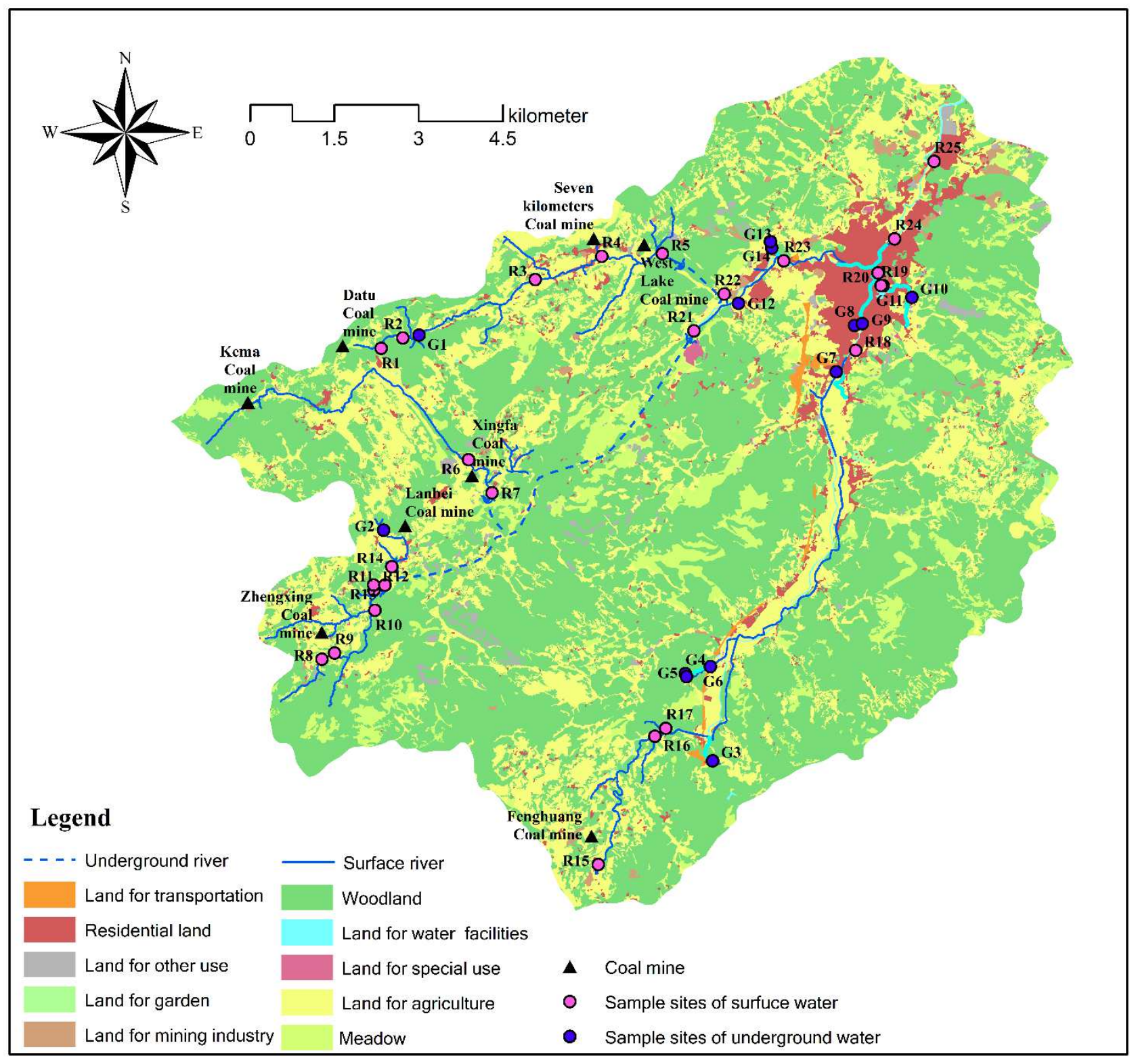

Fig.1 Sampling sites in Zhijin County, China(Li et al. 2021)

\section{Sampling}

According to the ground-surface water systems, a total of 39 water samples were collected in August 2016 (wet season) and January 2017 (dry season), of which 14 were groundwater samples, numbered G1G14; 25 were surface water samples, numbered R1-R25. The detailed distribution of sampling points is shown in Figure 1. The containers used for sampling were soaked in $5 \% \mathrm{HNO}_{3}$ for at least 24 hours and then washed with tap water and deionized water for 3 times to be dried for later use. A portable water quality parameter meter (Germany, Multi 3430) was used on site to measure the $\mathrm{pH}$ value, water 
temperature (T), oxidation-reduction potential (Eh), electrical conductivity (EC), and dissolved oxygen (DO) of the water samples. The concentration of $\mathrm{HCO}_{3}{ }^{-}$was titrated by $0.01 \mathrm{~mol} / \mathrm{L} \mathrm{HCl}$. The water samples were filtered by a $0.45 \mu \mathrm{m}$ cellulose acetate filter membrane and stored in two $50 \mathrm{~mL}$ polyethylene bottles. One for the analysis of cations $\left(\mathrm{K}^{+}, \mathrm{Na}^{+}, \mathrm{Ca}^{2+}, \mathrm{Mg}^{2+}, \mathrm{Mn}, \mathrm{Pb}, \mathrm{Cu}, \mathrm{Zn}, \mathrm{Cd}\right.$, etc.) was acidified to $\mathrm{pH}<2$ with ultrapure $\mathrm{HNO}_{3}$ and the other one was used for anions without adding any reagent. The samples were sealed with Parafilm sealing film and stored at low temperature $\left(4^{\circ} \mathrm{C}\right)$ in the dark until analysis.

\section{Analytical methods}

Major cations $\left(\mathrm{K}^{+}, \mathrm{Na}^{+}, \mathrm{Ca}^{2+}\right.$, and $\left.\mathrm{Mg}^{2+}\right)$ of all water samples and the $\mathrm{Mn}$ of surface water samples were determined by flame atomic absorption spectrophotometer (AAS, ICE3500, Thermo Fisher, USA), while the Mn of groundwater were analyzed by inductively coupled plasmamass spectrometry (ICP-MS; X-Series II, Thermo Fisher, USA) due to the relatively low concentrations. The anions $\left(\mathrm{Cl}^{-}, \mathrm{SO}_{4}{ }^{2-}\right.$ and $\left.\mathrm{NO}_{3}{ }^{-}\right)$of all water samples were determined by ion chromatography (IC, ICS-1100, Dionex, USA). All water samples were analyzed in the College of Resource and Environmental Engineering, Guizhou University, and the errors of anion and cation test analysis are $\pm 2 \%$ (Eq. 1 ).

$$
\mathrm{CBE}=\left[\frac{\sum \text { cations }-\sum \text { anions }}{\sum \text { cations }+\sum \text { anions }}\right] \times 100 \%
$$

Eq. 1

\section{Multi-statistical analysis of data}

The multi-statistical analysis of data was operated through the software Origin9.0.

\section{Nemerow Index Method}

According to the "Groundwater Quality Standards" and "Surface Water Environmental Quality Standards", Nemerow index were (Eq.2-Eq.3):

$$
\begin{aligned}
& \mathrm{F}=\sqrt{\frac{\mathrm{F}_{\mathrm{max}}^{2}+\overline{\mathrm{F}}^{2}}{2}} \\
& \overline{\mathrm{F}}=\frac{1}{\mathrm{n}} \sum_{\mathrm{i}=1}^{\mathrm{n}} \mathrm{F}_{\mathrm{i}}
\end{aligned}
$$

in the formula, $\mathrm{F}$ is the comprehensive evaluation index; $\overline{\mathrm{F}}$ is the score value of each single component; $F_{i}$ is the score value of each single component; $F_{\text {max }}$ is the maximum value of the single component score; $\mathrm{n}$ is the number of items. 
Table 1. Score table of each assessment factor

\begin{tabular}{cccccc}
\hline Level & I & II & III & IV & V \\
\hline $\mathrm{F}_{\mathrm{i}}$ & 0 & 1 & 3 & 6 & 10 \\
\hline
\end{tabular}

Table 2. Score table of Nemerow index

\begin{tabular}{cccccc}
\hline Class & Grade I & Grade II & Grade III & Grade IV & Grade V \\
\hline $\mathrm{F}$ & $<0.80$ & $0.80 \sim 2.50$ & $2.50 \sim 4.25$ & $4.25 \sim 7.20$ & $>7.20$ \\
\hline
\end{tabular}

\section{Results and analysis}

\section{Water chemistry}

According to the analysis results, the water samples in the study area can be divided into three categories: acid mine draniage (AMD), water samples with direct hydraulic connection with AMD (named AAMD), and water samples without direct hydraulic connection with AMD (named UAMD).

Table 3. Concentrations of water quality variables in AMD

\begin{tabular}{|c|c|c|c|c|c|c|c|c|c|}
\hline \multirow[t]{2}{*}{ Parameter } & \multirow[t]{2}{*}{ Unit } & \multicolumn{4}{|c|}{ Wet season } & \multicolumn{4}{|c|}{ Dry season } \\
\hline & & Mean & Min. & Max. & $\mathrm{CV}$. & Mean & Min. & Max. & $\mathrm{CV}$. \\
\hline $\mathrm{T}$ & ${ }^{\circ} \mathrm{C}$ & 20.9 & 19.2 & 22.4 & 0.057 & 9.8 & 8.3 & 13.0 & 0.160 \\
\hline $\mathrm{pH}$ & & 3.86 & 2.87 & 6.16 & 0.289 & 5.11 & 2.82 & 7.61 & 0.421 \\
\hline DO & $\mathrm{mg} / \mathrm{L}$ & 7.19 & 6.86 & 7.41 & 0.028 & 8.96 & 8.09 & 9.63 & 0.074 \\
\hline Eh & $\mathrm{mv}$ & 402.89 & 253.00 & 548.00 & 0.214 & 344.67 & 118.00 & 558.00 & 0.489 \\
\hline $\mathrm{Ec}$ & $\mu \mathrm{s} / \mathrm{cm}$ & 1651.67 & 556.00 & 2460.00 & 0.382 & 2330.00 & 828.00 & 3860.00 & 0.419 \\
\hline K & $\mathrm{mg} / \mathrm{L}$ & 2.69 & 1.06 & 4.75 & 0.438 & 1.62 & 0.33 & 3.51 & 0.659 \\
\hline $\mathrm{Ca}$ & $\mathrm{mg} / \mathrm{L}$ & 132.02 & 17.35 & 276.20 & 0.522 & 226.06 & 77.02 & 496.30 & 0.554 \\
\hline $\mathrm{Na}$ & $\mathrm{mg} / \mathrm{L}$ & 85.41 & 2.08 & 171.48 & 0.774 & 159.77 & 5.66 & 404.83 & 0.946 \\
\hline $\mathrm{Mg}$ & $\mathrm{mg} / \mathrm{L}$ & 44.69 & 12.19 & 98.99 & 0.580 & 75.33 & 23.95 & 181.30 & 0.677 \\
\hline $\mathrm{F}^{-}$ & $\mathrm{mg} / \mathrm{L}$ & 0.75 & 0.13 & 1.35 & 0.562 & 0.92 & 0.16 & 1.41 & 0.467 \\
\hline $\mathrm{Cl}$ & $\mathrm{mg} / \mathrm{L}$ & 1.84 & 0.51 & 3.08 & 0.478 & 1.75 & 0.29 & 5.10 & 0.877 \\
\hline $\mathrm{NO}_{3}$ & $\mathrm{mg} / \mathrm{L}$ & 4.56 & 2.62 & 7.43 & 0.389 & 2.11 & 0.78 & 3.04 & 0.337 \\
\hline $\mathrm{SO}_{4}$ & $\mathrm{mg} / \mathrm{L}$ & 1022.43 & 266.24 & 1756.54 & 0.477 & 1184.26 & 271.74 & 1968.01 & 0.465 \\
\hline $\mathrm{HCO}_{3}$ & $\mathrm{mg} / \mathrm{L}$ & 15.61 & 45.19 & 2.90 & 0.000 & 40.97 & 0.00 & 220.58 & 1.839 \\
\hline
\end{tabular}

Table 4. Concentrations of water quality variables in AAMD

\begin{tabular}{|c|c|c|c|c|c|c|c|c|c|}
\hline \multirow[t]{2}{*}{ Parameter } & \multirow[t]{2}{*}{ Unit } & \multicolumn{4}{|c|}{ Wet season } & \multicolumn{4}{|c|}{ Dry season } \\
\hline & & Mean & Min. & Max. & CV. & Mean & Min. & Max. & CV. \\
\hline $\mathrm{T}$ & ${ }^{\circ} \mathrm{C}$ & 17.2 & 15.6 & 18.1 & 0.043 & 14.6 & 9.0 & 16.0 & 0.132 \\
\hline $\mathrm{pH}$ & & 7.52 & 6.70 & 8.10 & 0.054 & 7.37 & 6.27 & 8.17 & 0.060 \\
\hline
\end{tabular}




\begin{tabular}{llllllllll}
$\mathrm{DO}$ & $\mathrm{mg} / \mathrm{L}$ & 6.85 & 2.10 & 8.16 & 0.236 & 6.49 & 1.01 & 8.95 & 0.337 \\
$\mathrm{Eh}$ & $\mathrm{mv}$ & 271.79 & 220.00 & 339.00 & 0.132 & 379.43 & 217.00 & 492.00 & 0.221 \\
$\mathrm{Ec}$ & $\mu \mathrm{s} / \mathrm{cm}$ & 370.43 & 217.00 & 546.00 & 0.257 & 411.21 & 196.00 & 538.00 & 0.244 \\
$\mathrm{~K}$ & $\mathrm{mg} / \mathrm{L}$ & 1.52 & 0.69 & 4.14 & 0.686 & 0.48 & 0.18 & 1.18 & 0.542 \\
$\mathrm{Ca}$ & $\mathrm{mg} / \mathrm{L}$ & 66.59 & 46.35 & 94.39 & 0.255 & 70.37 & 42.43 & 101.18 & 0.249 \\
$\mathrm{Na}$ & $\mathrm{mg} / \mathrm{L}$ & 3.81 & 0.53 & 10.87 & 0.774 & 6.47 & 0.74 & 15.68 & 0.735 \\
$\mathrm{Mg}$ & $\mathrm{mg} / \mathrm{L}$ & 7.11 & 1.20 & 12.54 & 0.452 & 10.06 & 0.92 & 24.59 & 0.526 \\
$\mathrm{~F}^{-}$ & $\mathrm{mg} / \mathrm{L}$ & 0.23 & 0.06 & 0.78 & 0.905 & 0.26 & 0.17 & 0.49 & 0.356 \\
$\mathrm{Cl}$ & $\mathrm{mg} / \mathrm{L}$ & 2.84 & 0.76 & 10.53 & 0.998 & 1.66 & 0.35 & 4.66 & 0.770 \\
$\mathrm{NO}_{3}$ & $\mathrm{mg} / \mathrm{L}$ & 11.52 & 5.89 & 27.00 & 0.606 & 7.19 & 2.06 & 10.82 & 0.385 \\
$\mathrm{SO}_{4}$ & $\mathrm{mg} / \mathrm{L}$ & 58.55 & 17.72 & 106.72 & 0.470 & 69.82 & 12.17 & 144.33 & 0.515 \\
$\mathrm{HCO}_{3}$ & $\mathrm{mg} / \mathrm{L}$ & 142.18 & 87.78 & 212.87 & 0.246 & 157.17 & 110.29 & 214.10 & 0.185 \\
$\mathrm{TDS}^{2}$ & $\mathrm{mg} / \mathrm{L}$ & 282.59 & 171.21 & 425.78 & 0.271 & 316.03 & 167.76 & 393.93 & 0.205 \\
\hline
\end{tabular}

Table 5. Concentrations of water quality variables in UAMD

\begin{tabular}{|c|c|c|c|c|c|c|c|c|c|}
\hline \multirow[t]{2}{*}{ Parameter } & \multirow[t]{2}{*}{ Unit } & \multicolumn{4}{|c|}{ Wet season } & \multicolumn{4}{|c|}{ Dry season } \\
\hline & & Mean & Min. & Max. & $\mathrm{CV}$. & Mean & Min. & Max. & $\mathrm{CV}$. \\
\hline $\mathrm{T}$ & ${ }^{\circ} \mathrm{C}$ & 19.2 & 16.9 & 22.3 & 0.073 & 11.8 & 8.7 & 15.0 & 0.140 \\
\hline $\mathrm{pH}$ & & 7.43 & 5.08 & 8.16 & 0.096 & 7.54 & 6.32 & 8.37 & 0.064 \\
\hline DO & $\mathrm{mg} / \mathrm{L}$ & 6.95 & 2.48 & 7.77 & 0.183 & 7.81 & 4.48 & 9.20 & 0.197 \\
\hline Eh & $\mathrm{mv}$ & 218.13 & -44.00 & 292.00 & 0.388 & 273.13 & 133.00 & 443.00 & 0.382 \\
\hline Ec & $\mu \mathrm{s} / \mathrm{cm}$ & 708.00 & 412.00 & 1554.00 & 0.473 & 836.94 & 443.00 & 2350.00 & 0.683 \\
\hline K & $\mathrm{mg} / \mathrm{L}$ & 2.15 & 1.28 & 3.68 & 0.315 & 2.10 & 0.54 & 5.90 & 0.733 \\
\hline $\mathrm{Ca}$ & $\mathrm{mg} / \mathrm{L}$ & 84.38 & 59.08 & 122.83 & 0.188 & 87.91 & 31.72 & 176.22 & 0.371 \\
\hline $\mathrm{Na}$ & $\mathrm{mg} / \mathrm{L}$ & 46.52 & 5.81 & 188.86 & 1.131 & 82.19 & 7.69 & 516.64 & 1.614 \\
\hline $\mathrm{Mg}$ & $\mathrm{mg} / \mathrm{L}$ & 14.23 & 3.25 & 32.73 & 0.576 & 14.03 & 7.36 & 54.72 & 0.812 \\
\hline $\mathrm{F}^{-}$ & $\mathrm{mg} / \mathrm{L}$ & 0.33 & 0.19 & 1.11 & 0.698 & 0.42 & 0.21 & 1.29 & 0.655 \\
\hline $\mathrm{Cl}$ & $\mathrm{mg} / \mathrm{L}$ & 2.60 & 1.00 & 5.59 & 0.454 & 3.28 & 0.71 & 10.17 & 0.697 \\
\hline $\mathrm{NO}_{3}$ & $\mathrm{mg} / \mathrm{L}$ & 6.73 & 1.58 & 9.70 & 0.314 & 4.98 & 1.09 & 10.98 & 0.496 \\
\hline $\mathrm{SO}_{4}$ & $\mathrm{mg} / \mathrm{L}$ & 259.51 & 74.25 & 656.96 & 0.688 & 219.22 & 61.10 & 685.76 & 0.837 \\
\hline $\mathrm{HCO}_{3}$ & $\mathrm{mg} / \mathrm{L}$ & 129.62 & 0.00 & 263.34 & 0.453 & 208.01 & 108.13 & 808.80 & 0.796 \\
\hline TDS & $\mathrm{mg} / \mathrm{L}$ & 538.10 & 313.72 & 1221.72 & 0.483 & 616.72 & 323.23 & 1973.96 & 0.699 \\
\hline
\end{tabular}

For AMD, pH values were relatively low with the ranges of 2.87-6.16 and 2.82-7.61 in the wet and the dry season respectively. And the $\mathrm{pH}$ values in the wet season were significantly lower than that in the dry season. In addition, compared with other sampling points, the $\mathrm{pH}$ at site $\mathrm{R} 1$ is relatively high (6.16 and 7.45 during the wet and dry seasons respectively). This may be owing to the effluent from this site flowed through the wind shaft rather than the coal mine. The $\mathrm{pH}$ values of UAMD were generally at a neutral value with the ranges of 6.7-8.1 and 6.3-8.2 in the wet and the dry season respectively. For AAMD, the pH values ranged from 5.1 to 8.2 in the wet season and from 6.3 to 8.4 in the dry season, showing the same seasonality as the $\mathrm{pH}$ values of $\mathrm{AMD}$ that the $\mathrm{pH}$ values in the wet season were lower than the dry season. 
As shown in Table 4 and Table 5, the average total dissolved solids(TDS) of AAMD in the study area during in the wet and the dry season were $539.00 \mathrm{mg} / \mathrm{L}$ and $616.74 \mathrm{mg} / \mathrm{L}$, which were in the same order of magnitude as the TDS of other rivers affected by AMD (Dabrowski et al. 2016) but higher than the TDS of world rivers (97 mg/L) (Meybeck 2003). For UAMD, the average values of UAMD in the study area during the wet and the dry seasons were $282.59 \mathrm{mg} / \mathrm{L}$ and $316.03 \mathrm{mg} / \mathrm{L}$, respectively, which were lower than the limits of class II in "Groundwater Quality Standards" (500 mg/L).

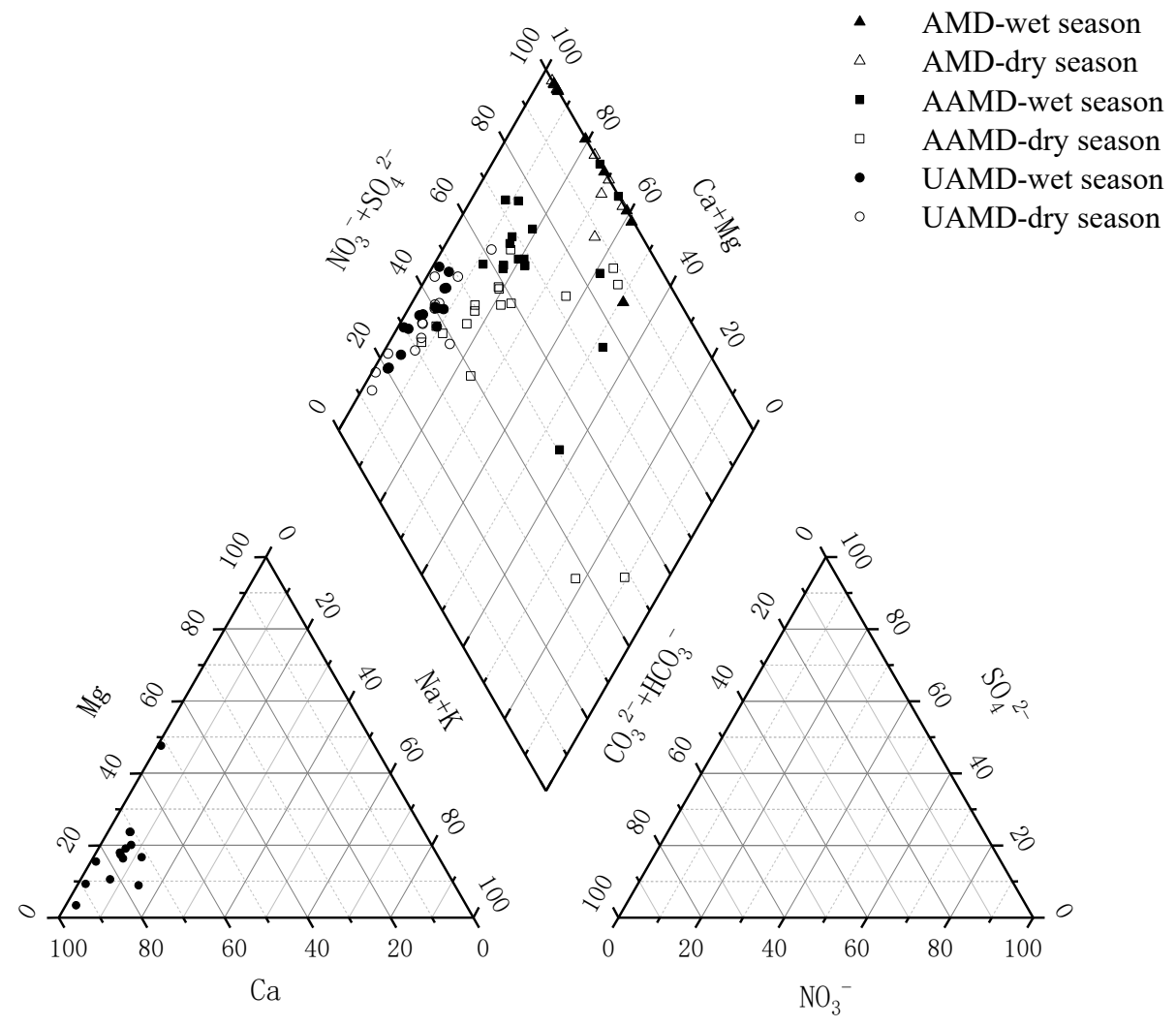

Fig. 2 Piper diagram

Piper diagrams help in the segregation of analytical data necessary for developing an understanding of the chemistry of water, which are used to assess the composition of cations and anions. It can be seen from the Piper diagram that there was no significant difference between wet and dry seasons. For AMD, the cations were mainly distributed in the $\mathrm{Ca} \cdot \mathrm{Mg}$ region, and the anions tended to $\mathrm{SO}_{4}{ }^{2-}$ end members, which means the hydrochemical type of $\mathrm{AMD}$ was $\mathrm{SO}_{4}-\mathrm{Ca} \cdot \mathrm{Mg}$ type. And the hydrochemical type of UAMD in the study area was $\mathrm{HCO}_{3}$-Ca type. For AAMD, the cations distributed widely that while most points distributed in the $\mathrm{Ca} \cdot \mathrm{Mg}$ area, some points tended to $\mathrm{Na}+\mathrm{K}$ end-members and the anions distributed in the $\mathrm{HCO}_{3} \cdot \mathrm{SO}_{4}$ area. Therefore, the hydrochemical type of AAMD was composed of $\mathrm{SO}_{4}-\mathrm{Ca} \cdot \mathrm{Mg}$ type, $\mathrm{HCO}_{3}-$ 
$\mathrm{Ca} \cdot \mathrm{Mg}$ type and $\mathrm{SO}_{4}-\mathrm{Na}$ type. Research has shown hydrochemical ions mainly came from the weathering of carbonate rocks by $\mathrm{H}_{2} \mathrm{CO}_{3}$ and $\mathrm{H}_{2} \mathrm{SO}_{4}$ (Han 2009).

\section{Spatial-temporal variations of metal elements, sulfate and nitrate nitrogen}

In the three kinds of water samples, the concentrations of metal elements (except $\mathrm{Ba}$ ) and sulfate followed the order: $A M D>A A M D>U A M D$, while the concentrations of metal $\mathrm{Ba}$ and nitrate nitrogen followed the opposite order: AMD $<$ AAMD $<$ UAMD (Fig.3). The order of the concentrations of metal elements and sulfate may be directly related to AMD with low $\mathrm{pH}$ and highly concentrated metals. Metal and sulfate concentrations were generally highest at AMD samples and decreased further downstream where AAMD samples sited due to the inflowing water. But the metal and sulfate concentrations of AAMD samples were still higher than that of UAMD without direct hydraulic connection with AMD. The metal and sulfate concentrations of UAMD were relatively low that lower than the acceptable limits of class III in "Groundwater Quality Standards". It's worth noting that compared with other sampling sites in UAMD, the concentrations of metals such as $\mathrm{Mn}, \mathrm{Co}, \mathrm{Ni}, \mathrm{Cu}$, As, etc. at the $\mathrm{G} 4$ were higher, with multiple maximum values, which may be owing to that the G4 site was close to the coal mine and was affected by the mining industry.

In order to better understand the temporal and spatial distribution characteristics of contaminants in water bodies, the spatial-temporal variations of contaminants in three main streams named Stream1, Stream2 and Stream3 (the water flow directions in Stream1, Stream2 and Stream3 were: R1-R2-R3-R4-R5-R22-R23R24-R25; R8-R9-R13-R14-R22-R23-R24-R25 and R15-R16-R18-R24-R25, respectively) were drawn (Figure 4(a)-(c)). 

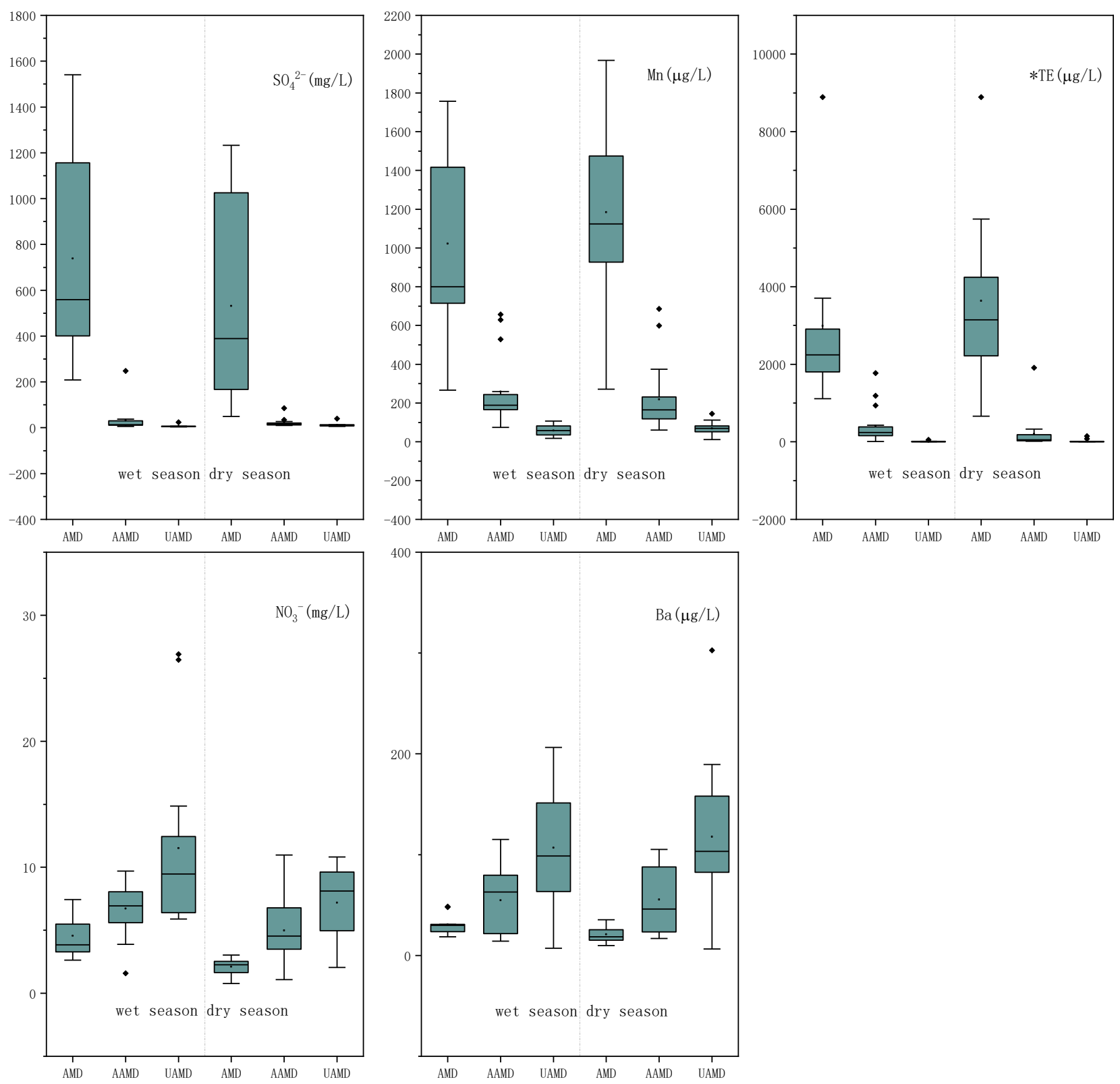

Fig.3 Boxplot of concentrations of contaminants in AMD, AAMD and UAMD

*TE indicates the total concentration of $\mathrm{Cr}, \mathrm{Co}, \mathrm{Ni}, \mathrm{Cu}, \mathrm{Zn}, \mathrm{Cd}, \mathrm{Sb}, \mathrm{Pb}$ and $\mathrm{As}$

\section{Spatial-temporal variations of metal elements and sulfates}

In Stream1, Stream2 and Stream3, the concentrations of metal elements (except Ba) and $\mathrm{SO}_{4}{ }^{2-}$ decreased along the water flow direction, which were mainly due to the dilution effect of inflowing water. However, the ochre deposits found on the river bank indicated that during the transport of highly concentrated Fe, Mn 
or other metal elements, various colloids and secondary minerals may be formed and precipitated, which could provoke rapid decreases of metal concentrations by absorption or coprecipitation(Caraballo et al. 2019; Carbone et al. 2013; Lee et al. 2002; Liu et al. 2017; Lozano et al. 2020; Lozano et al. 2018; SánchezEspaña et al. 2011). One the contrary, the concentration of Ba increased. It's because the precipitation of $\mathrm{BaSO}_{4}$ decreased with the decrease of $\mathrm{SO}_{4}{ }^{2-}$ concentration.

In Stream1 and Stream3, the concentrations of metal elements and $\mathrm{SO}_{4}{ }^{2-}$ were seasonally different that the concentrations of metal elements and $\mathrm{SO}_{4}{ }^{2-}$ were higher in wet season. Some studies have similar phenomena ( $\mathrm{Li}$ 2018) which is because the increase of flow in wet season results in the increase discharge of AMD which releases protons and metals. However, the concentrations of metal elements and $\mathrm{SO}_{4}{ }^{2-}$ in Stream 2 showed the opposite seasonal trend, which may be due to the relatively larger increase of the flow resulting the dilution of metal elements and $\mathrm{SO}_{4}{ }^{2-}$.

\section{Spatial-temporal variations of nitrate}

Contrary to the distribution characteristics of metal elements and sulfates, the concentration of nitrate increased along the flow (see Figure 4(a)-(c)). This may be because along the direction of the water flow, the nature of the study area has changed from mining-based to residential-based, which was affected by local agricultural activities and urban sewage. Studies have shown that nitrate in groundwater in this area is mainly affected by local agricultural activities and the process of urbanization.
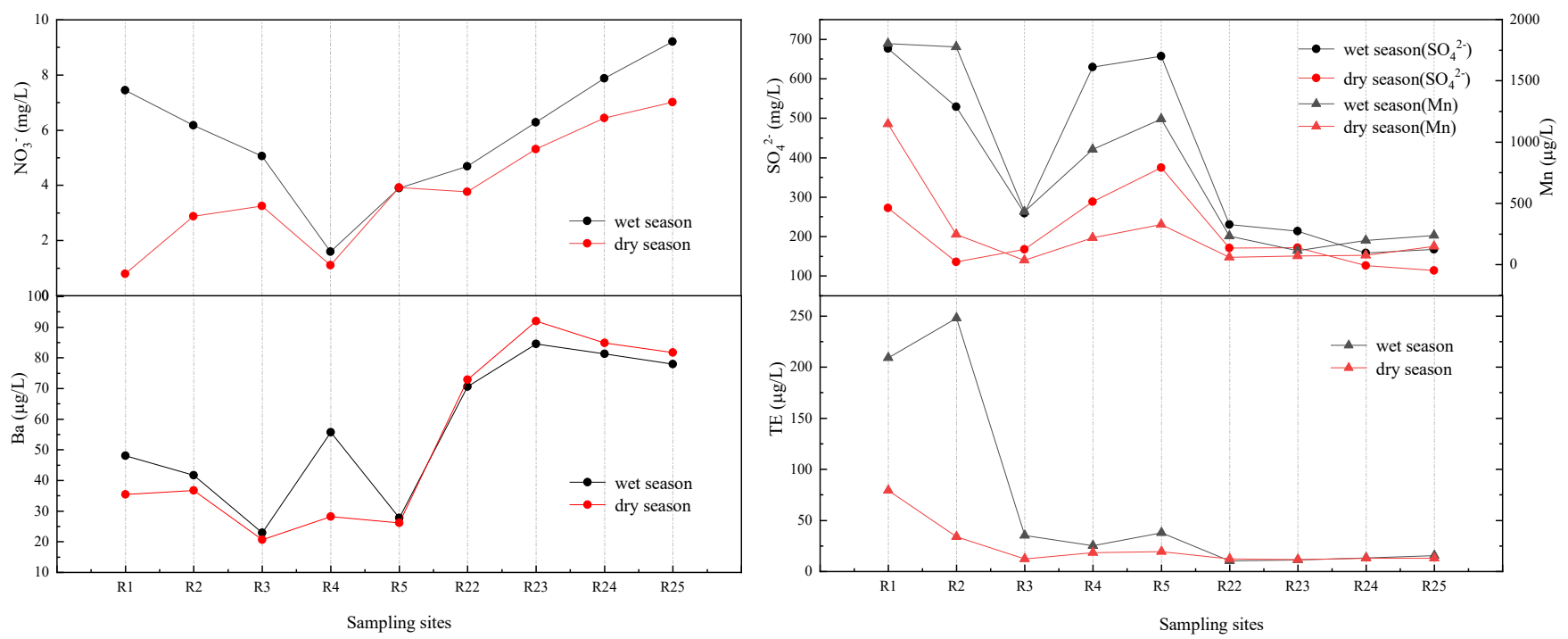

(a) Spatial-temporal variations of contaminants in Stream1 

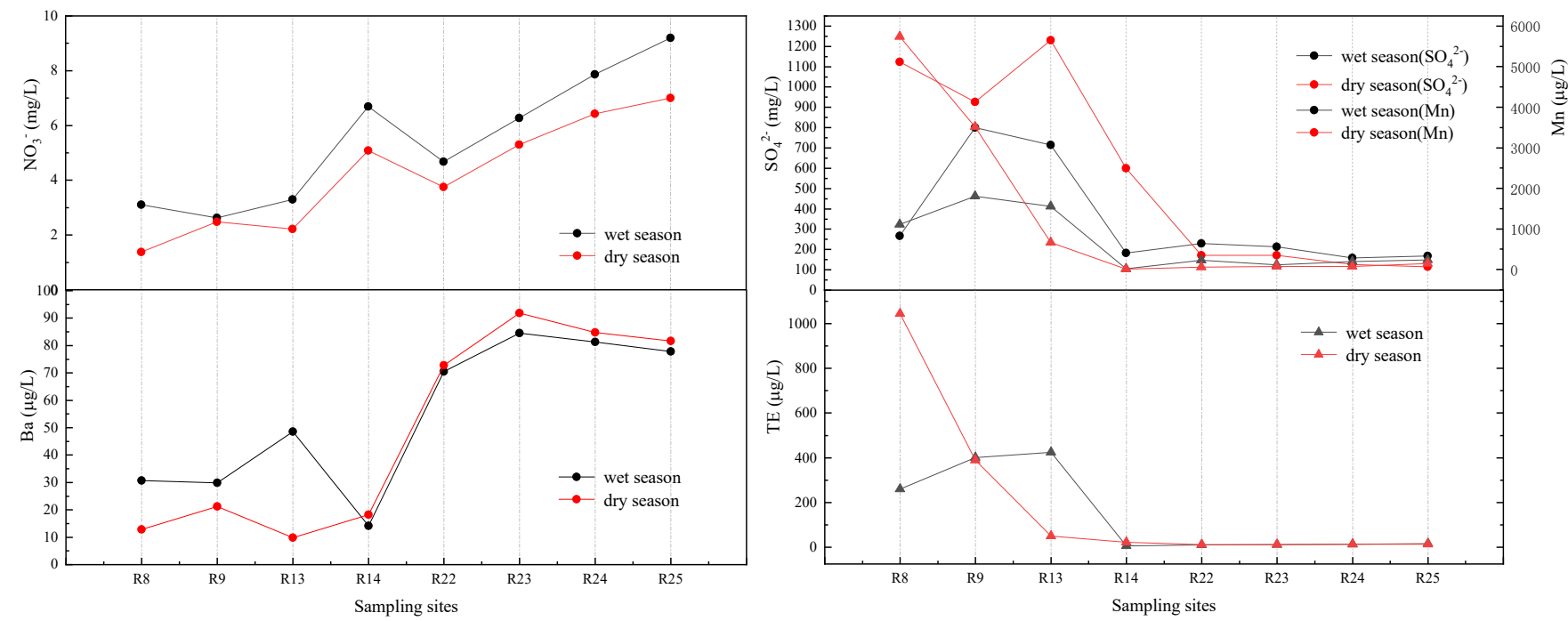

(b) Spatial-temporal variations of contaminants in Stream2
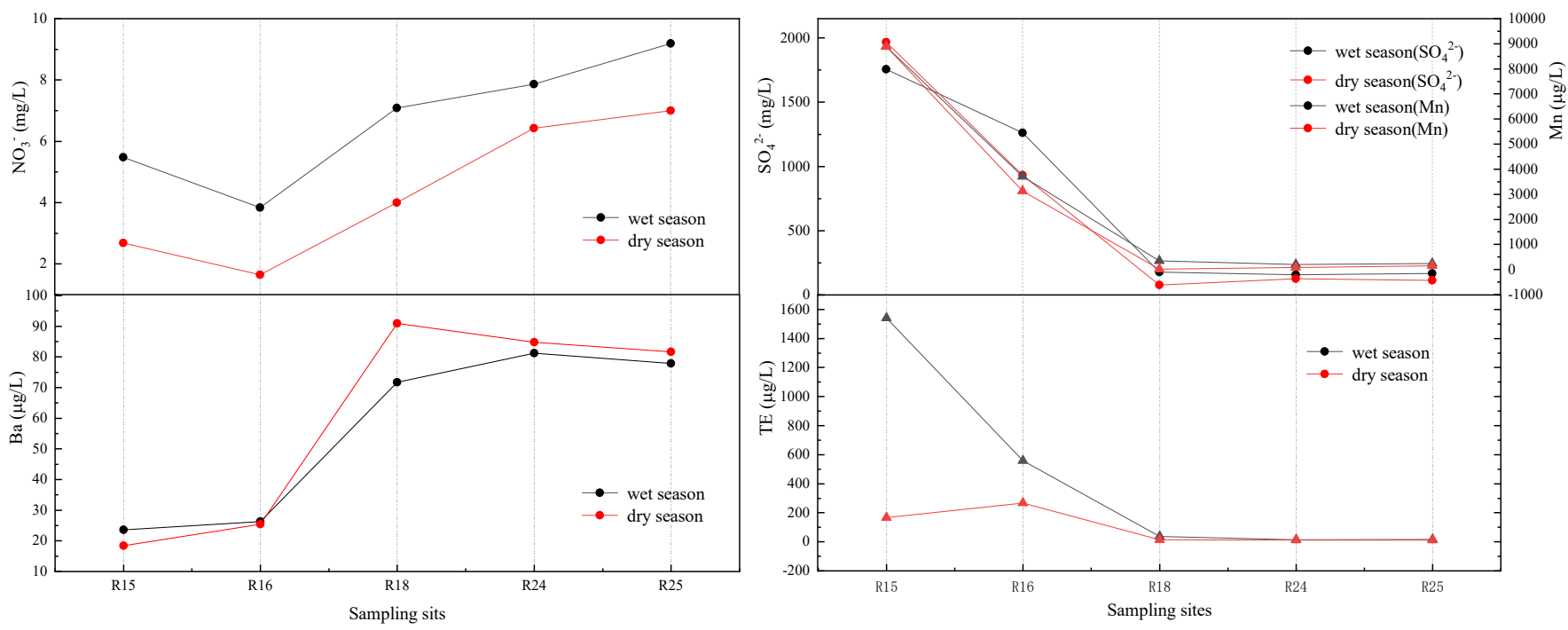

(c) Spatial-temporal variations of contaminants in Stream3

Fig.4 (a)-(c) Spatial-temporal variations of contaminants in Stream1, Stream2 and Stream3

*TE indicates the total concentration of $\mathrm{Cr}, \mathrm{Co}, \mathrm{Ni}, \mathrm{Cu}, \mathrm{Zn}, \mathrm{Cd}, \mathrm{Sb}, \mathrm{Pb}$ and $\mathrm{As}$

\section{Multivariate statistical analysis of pollutants}

The sources of contaminants in the water environment are complex, and the content is easily disturbed by external factors such as human activities. Therefore, a strong correlation between different contaminants means great possibility that they are derived from the same source. The Pearson correlation coefficient describes the contaminants concentrations (Table 6 and Table 7). Significant correlations between Co, Mn, 
$\mathrm{Ni}, \mathrm{Cu}, \mathrm{Zn}$ and $\mathrm{Cd}$ in UAMD shows that these elements may have the same source. And the significant correlations between $\mathrm{SO}_{4}{ }^{2-}, \mathrm{Co}, \mathrm{Mn}, \mathrm{Ni}$, and $\mathrm{Zn}$ indicates that these elements are derived from the same source, most likely related to the mining activities. PCA investigates five principal components, explaining $79.47 \%$ of the total variance. As shown in Table 8, for UAMD, PC1 accounts for $33.06 \%$ of the total variance and is characterized by the strong loading of Mn (0.90), Co (0.97), Ni (0.96), and $\mathrm{Zn}(0.87)$, and moderate loading of $\mathrm{SO}_{4}{ }^{2-}(0.66), \mathrm{Cu}(0.66)$, and $\mathrm{Cd}(0.58)$. Combined with the significant correlations between these elements, the loading of PC1 may be due to the groundwater-rock interactions and mining activities. PC2 contributes $18.05 \%$ of the total variance with strong loading of $\mathrm{NO}_{3}{ }^{-}(0.924)$ and $\mathrm{NO}_{2}-\mathrm{N}$ (0.832), which is generally related to the agricultural activities and urbanization processes. PC3, PC4, and PC5 accounting for $12.46 \%, 8.21 \%$ and $7.69 \%$ of the total variance, respectively, are characterized by with loading of $\mathrm{Cd}(0.66)$ and $\mathrm{Sb}(0.80), \mathrm{Cr}(0.86)$, and $\mathrm{NH}_{4}-\mathrm{N}(0.77)$, respectively, which may be attributed to the utilization of fertilizers for farmland and chemical behavior.

For AAMD, the Pearson matrix shows that many metals are significantly correlated. The significant correlations between $\mathrm{Mn}, \mathrm{Co}, \mathrm{Ni}, \mathrm{Cu}, \mathrm{Zn}, \mathrm{Cd}$ and $\mathrm{SO}_{4}{ }^{2-}$ indicate that these elements are derived from the same source. PCA investigates five principal components, explaining $75.06 \%$ of the total variance. As shown in Table 9, PC1 accounts for 33.52\% of the total variance and is characterized by the strong loading of $\mathrm{Mn}$ (0.80), $\mathrm{Co}(0.96), \mathrm{Ni}(0.94), \mathrm{Cu}(0.95)$, and $\mathrm{Zn}(0.91)$, and moderate loading of $\mathrm{SO}_{4}{ }^{2-}(0.54)$. Taking the low $\mathrm{pH}$ values of water samples, the hydrologically geographical characteristics of the study sites, and the significant correlations between these elements into consideration, the loading of PC1 may be due to the AMD occurred during mining activities. And according to the survey, about $1.825 \times 107 \mathrm{~m}^{3}$ of mine wastewater is discharges in Zhijin County every year(Li 2018).PC2 contributes $14.13 \%$ of the total variance with the loading of $\mathrm{NO}_{3}^{-}(0.76)$, which is generally related to the agricultural activities and domestic sewage. PC3, PC4, and PC5 accounting for $11.54 \%, 9.05 \%$ and $6.82 \%$ of the total variance, respectively, are characterized by with loading of $\mathrm{Cr}(0.86), \mathrm{Cd}(0.58), \mathrm{Sb}(0.63), \mathrm{As}(0.86)$, and $\mathrm{NH}_{4}-\mathrm{N}(0.86)$, respectively, which may be attributed to the utilization of fertilizers for farmland and chemical behavior. 
Table 6. Results of PCC in UAMD

\begin{tabular}{|c|c|c|c|c|c|c|c|c|c|c|c|c|c|c|c|c|c|c|}
\hline Items & $F$ & $\mathrm{Cl}$ & $\mathrm{HCO}_{3}^{-}$ & $\mathrm{NO}_{3}^{-}$ & $\mathrm{NH}_{4}-\mathrm{N}$ & $\mathrm{NO}_{2}-\mathrm{N}$ & $\mathrm{SO}_{4}^{2-}$ & $\mathrm{Cr}$ & $\mathrm{Mn}$ & Co & $\mathrm{Ni}$ & $\mathrm{Cu}$ & $\mathrm{Zn}$ & $\mathrm{Cd}$ & $\mathrm{Sb}$ & $\mathrm{Ba}$ & $\mathrm{Pb}$ & As \\
\hline $\mathrm{F}$ & 1.000 & -0.262 & -0.258 & -0.282 & -0.087 & -0.324 & -0.178 & -0.025 & -0.096 & -0.151 & -0.190 & -0.246 & -0.095 & -0.216 & -0.027 & -0.157 & -0.017 & 0.110 \\
\hline $\mathrm{Cl}$ & & 1.000 & $0.618^{*}$ & $0.929 *$ & -0.021 & $0.573^{*}$ & 0.229 & -0.010 & -0.054 & -0.080 & 0.057 & -0.207 & -0.253 & -0.159 & -0.250 & 0.365 & -0.279 & -0.250 \\
\hline $\mathrm{HCO}_{3}^{-}$ & & & 1.000 & $0.548^{*}$ & 0.043 & 0.171 & 0.232 & $0.417 *$ & -0.227 & -0.235 & -0.089 & -0.091 & -0.237 & -0.116 & 0.158 & $0.398 *$ & 0.180 & -0.418 \\
\hline $\mathrm{NO}_{3}^{-}$ & & & & 1.000 & 0.026 & $0.727^{*}$ & 0.198 & -0.140 & -0.112 & -0.110 & 0.030 & -0.163 & -0.319 & -0.168 & -0.150 & $0.425^{*}$ & -0.425 & -0.277 \\
\hline $\mathrm{NH}_{4}-\mathrm{N}$ & & & & & 1.000 & -0.085 & 0.103 & 0.104 & -0.052 & -0.033 & -0.042 & -0.143 & -0.063 & -0.024 & -0.071 & 0.209 & -0.101 & -0.057 \\
\hline $\mathrm{NO}_{2}-\mathrm{N}$ & & & & & & 1.000 & 0.114 & -0.230 & -0.055 & -0.021 & 0.082 & -0.034 & -0.224 & -0.204 & -0.170 & 0.027 & -0.354 & -0.193 \\
\hline $\mathrm{SO}_{4}^{2-}$ & & & & & & & 1.000 & 0.336 & $0.460 *$ & $0.534 *$ & $0.644 *$ & 0.323 & $0.384 *$ & 0.050 & -0.283 & 0.105 & -0.132 & -0.176 \\
\hline $\mathrm{Cr}$ & & & & & & & & 1.000 & 0.176 & 0.052 & 0.047 & 0.020 & 0.275 & 0.010 & -0.003 & 0.355 & $0.552 *$ & -0.158 \\
\hline $\mathrm{Mn}$ & & & & & & & & & 1.000 & 0.893* & $0.844 *$ & $0.498^{*}$ & $0.809^{*}$ & $0.514 *$ & -0.043 & -0.066 & 0.030 & 0.129 \\
\hline Co & & & & & & & & & & 1.000 & $0.959 *$ & $0.614 *$ & $0.877^{*}$ & $0.572 *$ & -0.068 & -0.109 & -0.026 & 0.164 \\
\hline $\mathrm{Ni}$ & & & & & & & & & & & 1.000 & $0.595 *$ & $0.779 *$ & $0.479 *$ & -0.099 & -0.064 & -0.086 & 0.033 \\
\hline $\mathrm{Cu}$ & & & & & & & & & & & & 1.000 & $0.615^{*}$ & $0.697 *$ & 0.271 & -0.211 & 0.278 & 0.249 \\
\hline $\mathrm{Zn}$ & & & & & & & & & & & & & 1.000 & $0.638^{*}$ & 0.145 & -0.184 & 0.238 & 0.353 \\
\hline $\mathrm{Cd}$ & & & & & & & & & & & & & & 1.000 & 0.302 & -0.072 & 0.234 & $0.431^{*}$ \\
\hline $\mathrm{Sb}$ & & & & & & & & & & & & & & & 1.000 & -0.099 & 0.328 & 0.263 \\
\hline $\mathrm{Ba}$ & & & & & & & & & & & & & & & & 1.000 & -0.184 & -0.253 \\
\hline $\mathrm{Pb}$ & & & & & & & & & & & & & & & & & 1.000 & -0.037 \\
\hline As & & & & & & & & & & & & & & & & & & 1.000 \\
\hline
\end{tabular}

*indicates significant correlation

Table 7. Results of PCC in AAMD

\begin{tabular}{|c|c|c|c|c|c|c|c|c|c|c|c|c|c|c|c|c|c|c|}
\hline Items & $\mathrm{F}$ & $\mathrm{Cl}$ & $\mathrm{HCO}_{3}^{-}$ & $\mathrm{NO}_{3}{ }^{-}$ & $\mathrm{NH}_{4}-\mathrm{N}$ & $\mathrm{NO}_{2}-\mathrm{N}$ & $\mathrm{SO}_{4}{ }^{2-}$ & $\mathrm{Cr}$ & $\mathrm{Mn}$ & $\mathrm{Co}$ & $\mathrm{Ni}$ & $\mathrm{Cu}$ & $\mathrm{Zn}$ & $\mathrm{Cd}$ & $\mathrm{Sb}$ & $\mathrm{Ba}$ & $\mathrm{Pb}$ & As \\
\hline $\mathrm{F}$ & 1.000 & 0.078 & $0.699 *$ & -0.019 & -0.121 & $\begin{array}{l}0.177 \\
\end{array}$ & 0.258 & $0.602 *$ & -0.045 & -0.093 & -0.111 & -0.108 & -0.137 & -0.058 & 0.134 & -0.083 & -0.039 & 0.319 \\
\hline $\mathrm{Cl}$ & & 1.000 & 0.031 & -0.093 & 0.016 & 0.087 & -0.031 & 0.088 & 0.165 & 0.068 & 0.098 & -0.061 & -0.058 & -0.090 & $0.731^{*}$ & -0.011 & 0.104 & $0.627^{*}$ \\
\hline $\mathrm{HCO}_{3}^{-}$ & & & 1.000 & -0.186 & -0.160 & -0.125 & 0.292 & $0.892 *$ & -0.240 & -0.282 & -0.295 & -0.231 & -0.244 & -0.052 & 0.182 & -0.162 & 0.091 & $0.392 *$ \\
\hline $\mathrm{NO}_{3}^{-}$ & & & & 1.000 & 0.114 & $0.480 *$ & -0.486 & -0.196 & -0.349 & -0.180 & -0.212 & -0.017 & 0.007 & -0.024 & -0.190 & 0.251 & 0.055 & 0.081 \\
\hline $\mathrm{NH}_{4}-\mathrm{N}$ & & & & & 1.000 & $0.443 *$ & 0.316 & -0.311 & 0.341 & 0.159 & 0.187 & 0.011 & -0.101 & -0.214 & -0.189 & -0.031 & -0.315 & -0.040 \\
\hline $\mathrm{NO}_{2}-\mathrm{N}$ & & & & & & 1.000 & -0.178 & -0.309 & -0.071 & -0.143 & -0.164 & -0.186 & -0.162 & -0.327 & -0.133 & $0.537 *$ & -0.271 & 0.181 \\
\hline $\mathrm{SO}_{4}{ }^{2-}$ & & & & & & & 1.000 & 0.173 & $0.777 *$ & $0.575^{*}$ & $0.572 *$ & $0.399 *$ & 0.248 & 0.199 & -0.148 & -0.481 & -0.258 & -0.188 \\
\hline $\mathrm{Cr}$ & & & & & & & & 1.000 & -0.257 & -0.223 & -0.200 & -0.127 & -0.119 & 0.106 & 0.193 & -0.133 & $0.388^{*}$ & 0.262 \\
\hline $\mathrm{Mn}$ & & & & & & & & & 1.000 & $0.880 *$ & $0.886^{*}$ & $0.646 *$ & $0.539 *$ & 0.343 & -0.050 & -0.315 & -0.261 & -0.196 \\
\hline Co & & & & & & & & & & 1.000 & $0.989^{*}$ & $0.902 *$ & $0.845^{*}$ & $0.624 *$ & -0.005 & -0.231 & -0.214 & -0.148 \\
\hline $\mathrm{Ni}$ & & & & & & & & & & & 1.000 & $0.866^{*}$ & $0.809^{*}$ & $0.606^{*}$ & -0.005 & -0.239 & -0.158 & -0.176 \\
\hline $\mathrm{Cu}$ & & & & & & & & & & & & 1.000 & $0.970 *$ & $0.758^{*}$ & -0.047 & -0.162 & -0.080 & -0.132 \\
\hline $\mathrm{Zn}$ & & & & & & & & & & & & & 1.000 & $0.785^{*}$ & -0.024 & -0.007 & 0.005 & -0.094 \\
\hline $\mathrm{Cd}$ & & & & & & & & & & & & & & 1.000 & 0.037 & -0.087 & 0.060 & -0.125 \\
\hline $\mathrm{Sb}$ & & & & & & & & & & & & & & & 1.000 & -0.065 & 0.030 & $0.819^{*}$ \\
\hline $\mathrm{Ba}$ & & & & & & & & & & & & & & & & 1.000 & 0.236 & 0.066 \\
\hline $\mathrm{Pb}$ & & & & & & & & & & & & & & & & & 1.000 & -0.057 \\
\hline As & & & & & & & & & & & & & & & & & & 1.000 \\
\hline
\end{tabular}

*indicates significant correlation 
Table 8. Results of the principal component analysis in UAMD

\begin{tabular}{crrrrr}
\hline Variable & \multicolumn{1}{c}{ PC1 } & \multicolumn{1}{c}{ PC2 } & \multicolumn{1}{c}{ PC3 } & \multicolumn{1}{c}{ PC4 } & \multicolumn{1}{c}{ PC5 } \\
\hline $\mathrm{NO}_{3}$ & -0.058 & 0.924 & -0.078 & -0.087 & 0.183 \\
$\mathrm{SO}_{4}{ }^{2-}$ & 0.661 & 0.206 & -0.4 & 0.212 & 0.139 \\
$\mathrm{NH}_{4}-\mathrm{N}$ & -0.021 & -0.146 & -0.071 & -0.075 & 0.774 \\
$\mathrm{NO}_{2}-\mathrm{N}$ & 0.003 & 0.832 & -0.117 & -0.198 & -0.189 \\
$\mathrm{Cr}$ & 0.149 & -0.130 & -0.077 & 0.864 & 0.251 \\
$\mathrm{Mn}$ & 0.900 & -0.069 & 0.014 & 0.028 & -0.003 \\
$\mathrm{Co}$ & 0.973 & -0.048 & 0.029 & -0.075 & -0.023 \\
$\mathrm{Ni}$ & 0.961 & 0.101 & -0.059 & -0.043 & -0.034 \\
$\mathrm{Cu}$ & 0.664 & 0.01 & 0.473 & 0.088 & -0.238 \\
$\mathrm{Zn}$ & 0.865 & -0.273 & 0.240 & 0.105 & -0.046 \\
$\mathrm{Cd}$ & 0.579 & -0.118 & 0.661 & -0.034 & 0.048 \\
$\mathrm{Sb}$ & -0.108 & -0.035 & 0.801 & 0.155 & -0.093 \\
$\mathrm{Ba}$ & -0.084 & 0.401 & -0.014 & 0.318 & 0.697 \\
$\mathrm{~Pb}$ & -0.016 & -0.357 & 0.317 & 0.740 & -0.280 \\
$\mathrm{As}$ & 0.147 & -0.343 & 0.549 & -0.43 & 0.039 \\
Eigenvalues & 4.709 & 2.708 & 1.868 & 1.233 & 1.153 \\
Proportion to the total variance $\%$ & 33.057 & 18.051 & 12.455 & 8.221 & 7.686 \\
Cumulative percent $\%$ & 33.057 & 51.108 & 63.563 & 71.784 & 79.47 \\
\hline
\end{tabular}

Table 9. Results of the principal component analysis in AAMD

\begin{tabular}{crrrrr}
\hline Variable & \multicolumn{1}{c}{ PC1 } & \multicolumn{1}{c}{ PC2 } & \multicolumn{1}{c}{ PC3 } & \multicolumn{1}{c}{ PC4 } & \multicolumn{1}{c}{ PC5 } \\
\hline $\mathrm{NO}_{3}$ & -0.107 & 0.764 & -0.192 & -0.187 & -0.007 \\
$\mathrm{SO}_{4}{ }^{2-}$ & 0.540 & -0.569 & -0.022 & -0.235 & 0.368 \\
$\mathrm{NH}_{4}-\mathrm{N}$ & 0.054 & 0.121 & -0.116 & 0.017 & 0.860 \\
$\mathrm{NO}_{2}-\mathrm{N}$ & -0.059 & -0.156 & -0.571 & -0.161 & 0.267 \\
$\mathrm{Cr}$ & -0.137 & -0.129 & 0.802 & 0.011 & 0.252 \\
$\mathrm{Mn}$ & 0.798 & -0.378 & -0.199 & -0.113 & 0.217 \\
$\mathrm{Co}$ & 0.962 & -0.164 & -0.121 & -0.025 & 0.067 \\
$\mathrm{Ni}$ & 0.941 & -0.220 & -0.099 & -0.042 & 0.091 \\
$\mathrm{Cu}$ & 0.950 & -0.020 & 0.003 & 0.000 & -0.054 \\
$\mathrm{Zn}$ & 0.907 & 0.125 & 0.092 & 0.134 & -0.156 \\
$\mathrm{Cd}$ & 0.386 & 0.272 & 0.239 & 0.578 & -0.177 \\
$\mathrm{Sb}$ & -0.06 & -0.164 & 0.139 & 0.635 & 0.097 \\
$\mathrm{Ba}$ & -0.134 & 0.819 & 0.108 & -0.061 & 0.188 \\
$\mathrm{~Pb}$ & -0.083 & -0.059 & 0.758 & 0.005 & -0.165 \\
$\mathrm{As}$ & -0.087 & -0.083 & -0.103 & 0.858 & -0.060 \\
Eigenvalues & 5.028 & 2.119 & 1.731 & 1.358 & 1.023 \\
Proportion to the total variance $\%$ & 33.518 & 14.128 & 11.543 & 9.054 & 6.820 \\
Cumulative percent\% & 33.518 & 47.646 & 59.189 & 68.243 & 75.063 \\
\hline
\end{tabular}

\subsection{The assessment of water quality}


Based on the "Groundwater Quality Standards" and "Surface Water Quality Standards", $\mathrm{pH}, \mathrm{F}^{-}, \mathrm{Cl}^{-}, \mathrm{SO}_{4}{ }^{2-}$, $\mathrm{NH}_{4}-\mathrm{N}, \mathrm{NO}_{2}-\mathrm{N}, \mathrm{Cr}, \mathrm{Mn}, \mathrm{Co}, \mathrm{Ni}, \mathrm{Cu}, \mathrm{Zn}, \mathrm{As}, \mathrm{Cd}, \mathrm{Sb}$ and other factors were analyzed for water quality assessment, and the Nemerow indexes of AMD, AAMD and UAMD were calculated, respectively (Fig.5).

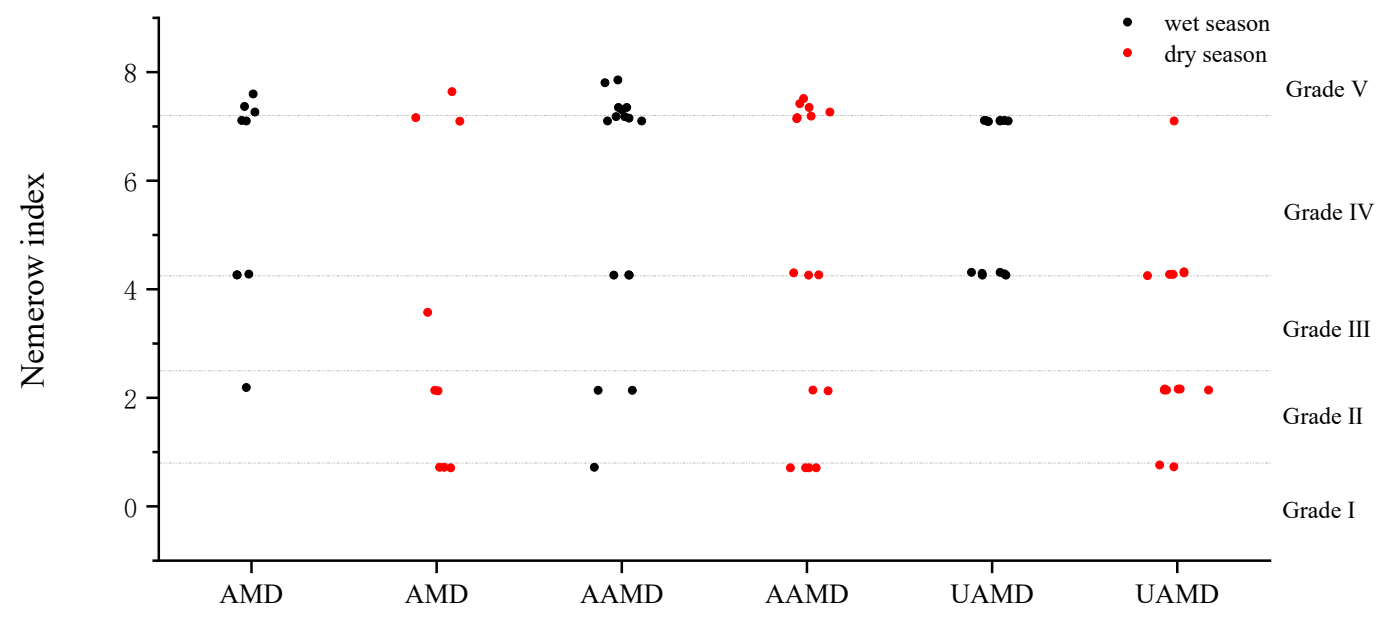

Fig.5 Results of Nemerow method

According to Fig.5, for UAMD, 19 of the 28 water samples, accounting about $68 \%$, are divided into Grade IV, mainly related to $\mathrm{NH}_{4}-\mathrm{N}$. For AAMD and AMD, 19 and 14 of the 50 water samples, accounting $66 \%$, are divided into Grade IV and Grade V, respectively, mainly related to $\mathrm{pH}, \mathrm{NH}_{4}-\mathrm{N}, \mathrm{Mn}, \mathrm{Cu}$, and $\mathrm{Zn}$. Compared to the UAMD, the water quality of AMD and AAMD are significantly affected by the metal elements. Therefore, the water quality of AAMD is mainly controlled by the mining activities while the water quality of UAMD is mainly controlled by the agricultural activities and urbanization.

\section{Conclusion}

(1) In the three kinds of water samples, the order of concentrations of metal elements (except $\mathrm{Ba}$ ) and sulfate was: $A M D>A A M D>U A M D$, while the concentrations of metal $\mathrm{Ba}$ and nitrate nitrogen show the opposite concentration order: AMD $<$ AAMD $<$ UAMD.

(2) On the spatial scale, the concentrations of metal elements (except $\mathrm{Ba}$ ) and $\mathrm{SO}_{4}{ }^{2-}$ showed an overall decreasing trend along the flow direction, and the concentrations of metal elements $\mathrm{Ba}$ and nitrate nitrogen showed an upward trend along the flow direction.

(3) On the temporal scale, in Stream1 and Stream3, the concentrations of metal elements (except Ba) and $\mathrm{SO}_{4}{ }^{2-}$ in the water samples were significantly affected by the season, which were higher in wet season than dry season. This may be due to the increase in AMD during the wet season, which intensified the release of heavy metals. However, in Stream2, the concentrations of metal elements (except Ba) and $\mathrm{SO}_{4}{ }^{2-}$ showed 
opposite seasonal trends, which may be due to the relatively larger increase in the flow rate of Stream2 during the wet season, which diluted the concentrations of metal elements and $\mathrm{SO}_{4}{ }^{2-}$ instead.

(4) PCC and PCA analysis indicate that water pollution was mainly affected by mining industry activities, agricultural activities and urbanization. The Nemerow index shows that in UAMD water samples, $68 \%$ are divided into Grade IV, mainly related to $\mathrm{NH}_{4} \mathrm{~N}$; in AMD and AAMD water samples, $66 \%$ are divided into Grade IV and Grade V, mainly related to $\mathrm{pH}, \mathrm{NH}_{4}-\mathrm{N}, \mathrm{Mn}, \mathrm{Cu}$, and $\mathrm{Zn}$. Therefore, the water quality of AAMD water quality is mainly affected by mining activities, while the water quality of UAMD is mainly affected by agricultural activities and urbanization.

\section{Funding}

This work was supported by the National Natural Science Foundation of China, Project of Karst Scientific Research Center of the People's Government of Guizhou Province(U1612442), the High Level Talent Training Program in Guizhou ([2016]5664), and the Project of Talent Base of Guizhou Province (No.RCJD2018).

\section{Competing interests}

The authors declare that they have no known competing financial interests or personal relationships that could have appeared to influence the work reported in this paper. 


\section{References}

Abulimiti A, Wang J, Wang H, Sawut R, Abliz A, Hasan U (2017) Spatial distribution analysis of heavy metals in soil and atmospheric dust fall and their relationships in Xinjiang Eastern Junggar mining area. Transactions of the Chinese Society of Agricultural Engineering 33:259-266. https://doi.org/10.11975/j.issn.1002-6819.2017.23.034

Alpers CN, Blowes DW (1994) Environmental geochemistry of sulfide oxidation. In: American Chemical Society Symposium Series.

An L, zhao Q, Ye S, Liu G, Ding X (2012) Hydrochemical Characteristics and Formation Mechanism of Shallow Groundwater in the Yellow River Delta. Environmental Science:370-378.

Blowes DW, Ptacek CJ, Jambor JL, Weisener CG, Paktunc D, Gould WD, Johnson DB (2014) The Geochemistry of Acid Mine Drainage. Treatise on Geochemistry 11:131-190. https://doi.org/10.1016/B978-0-08-095975-7.00905-0

Caraballo MA, Wanty RB, Verplanck PL, Navarro-Valdivia L, Ayora C, Hochella MFJCG (2019) Aluminum mobility in mildly acidic mine drainage: Interactions between hydrobasaluminite, silica and trace metals from the nano to the meso-scale. Chemical Geology. https://doi.org/10.1016/j.chemgeo.2019.04.013

Carbone C, Dinelli E, Marescotti P, Gasparotto G, Lucchetti G (2013) The role of AMD secondary minerals in controlling environmental pollution: indications from bulk leaching tests. Journal of Geochemical Exploration 132:188-200. https://doi.org/10.1016/j.gexplo.2013.07.001

Chen D, Xie Z, Zhang Y, Luo X, Guo Q, Yang J, Liang Y (2016) Source Apportionment of Soil Heavy Metals in Guangzhou Based on the PCA/APCS Model and Geostatistics. Ecology and Environmental Sciences 25:1014-1022.

Cui J, Li X, Shi H, Sun Y, An H, Xing J (2020) Chemical Evolution and Formation Mechanism of Groundwater in Hetao Irrigation Area. Environmental Science.

Dabrowski JM, Dabrowski J, Hill L, Macmillan P, Oberholster PJ (2016) Fate, Transport and Effects of Pollutants Originating from Acid Mine Drainage in the Olifants River, South Africa. River Research and Applications:1354-1364. https://doi.org/10.1002/rra.2833

Gao X et al. (2018) Seasonal Variation Characteristics of Pollution Risk in a Riverside Source Area Based on Source Apportionment. Environmental Science 39:4086-4095.

Han Z (2009) Analysis of the impact of large-scale hydropower projects on the chemical composition of river water. Dissertation, Guizhou University.

Huifen K, Chunhua H, Genlin W, Miao C (2020) Combination of PCA and PMF to apportion the sources of heavy metals in surface sediments from Lake Poyang during the wet season. Journal of Lake Sciences 32:964-976. https://doi.org/10.18307/2020.0406

Lee G, Bigham JM, Faure GJAG (2002) Removal of trace metals by coprecipitation with Fe, Al and Mn from natural waters contaminated with acid mine drainage in the Ducktown Mining District, Tennessee. Applied Geochemistry 17:569-581. https://doi.org/10.1016/S0883-2927(01)00125-1

$\mathrm{Li}$ et al. (2018) Effects of mining activities on evolution of water chemistry in coal-bearing aquifers in karst region of Midwestern Guizhou, China: evidences from delta C-13 of dissolved inorganic carbon and delta S-34 of sulfate. Environmental Science \& Pollution Research. https://doi.org/ 10.1007/s11356-018-1969-3

Li X (2018) Study on hydrogeochemical characteristics and evolution rules of Karst basin under the effects of acid mine waste water. Dissertation, Guizhou University.

Li X, Li J, Wu Y, Sun M, Wang D, Du L, Xiong D (2017) Analysis and Evaluation of the Water Quality of Water Disperse supply in Zhijin Water Shortage Rural Area of Guizhou Province. Journal of Guizhou University(Natural Sciences) 34:126-131. 
Li X, Wu P, Zha X, He S, Wu L, Han Z (2021) Tracing nitrate sources in urban waters of Karst mountainous area using hydrochemistry and stable isotope. Acta Scientiae Circumstantiae:1-12.

Liu Q, Chen B, Zhou Y, Zou Q, Chen Y, Cheng Y (2017) A Study on Secondary Minerals in Different Sediments of Caoduikeng Acid Mine Drainage, Dabaoshan Mine, North Guangdong Province, China. Earth and Environment 045:259-266.

Lottermoser BGJS (2010) Mine Wastes / Characterization, Treatment and Environmental Impacts.

Lozano A, Ayora C, Fernández-Martínez AJAG (2020) Sorption of rare earth elements on schwertmannite and their mobility in acid mine drainage treatments. Applied Geochemistry 113:104499. https://doi.org/10.1016/j.apgeochem.2019.104499

Lozano A, Fernández-Martínez A, Ayora C, Poulain AJCG (2018) Local structure and ageing of basaluminite at different $\mathrm{pH}$ values and sulphate concentrations. Chemical Geology 496:25-33. https://doi.org/10.1016/j.chemgeo.2018.08.002

Lumb A, Sharma TC, Bibeault JF (2011) A Review of Genesis and Evolution of Water Quality Index (WQI) and Some Future Directions. Water Quality, Exposure and Health 3:11-24. https://doi.org/10.1007/s12403-011-0040-0

McCarthy, Terence SJSAJoS (2011) The impact of acid mine drainage in South Africa. South African Journal of Science 107:1---7. https://doi.org/10.4102/sajs.v107i5/6.712

Meybeck M (2003) Global Occurrence of Major Elements in Rivers.

Oki, Taikan, Kanae, Shinjiro (2006) Global Hydrological Cycles and World Water Resources. Science. https://doi.org/10.1126/science.1128845

Sánchez-España J, Yusta I, Diez-Ercilla MJAG (2011) Schwertmannite and hydrobasaluminite: A reevaluation of their solubility and control on the iron and aluminium concentration in acidic pit lakes. Applied Geochemistry 26:1752-1774. https://doi.org/10.1016/j.apgeochem.2011.06.020

Shi J, Wu P, Zhang R, Li X, Zha Xa (2016) Water Quality Characteristics and Irrigation Suitability Evaluation Under the Influence of Coal Mine Drainage - -A Case Study of the River Watershed in Zhijin,Guizhou. Water Saving Irrigation:71-76.

Szulczewski MJJoPOC (2015) Continuing Acid Mine Drainage Impacts On the Environmental Health of the Soils, Streams, and Macroinvertebrates In a Virginia Ecosystem. Journal of Physical Organic Chemistry 18:929-934. https://doi.org/10.1002/poc.919

Weimin et al. (2016) Profiling microbial community in a watershed heavily contaminated by an active antimony (Sb) mine in Southwest China. Science of The Total Environment. https://doi.org/10.1016/j.scitotenv.2016.01.090

Wu C, Li H (2014) Application of water quality indices in integrated water quality assessment:a review of recent studies. Journal of Environment and Health:87-89.

Yang Y, Zhao H, Meng R, He L, Zhao H, Du S, Ding T (2020) Sources and Ecological Risk Assessment of Polycyclic Aromatic Hydrocarbons in the Jiaxing River Network. Environmental Science:1-14.

Zheng Y, Wang H, Qin Q, Yang D, Wang Y, Zhang Z (2020) Water quality assessment and spatial difference of the Sunxi River watershed in the Three Gorges Reservoir area. Journal of Hydroecology:1-14.

Zhuo H, Wang X, Liu H, Fu S, Ren L (2020) Source analysis and risk assessment of heavy metals in development zones: a case study in Rizhao, China. Environmental Geochemistry and Health. https://doi.org/10.1007/s10653-019-00313-7 
Figures

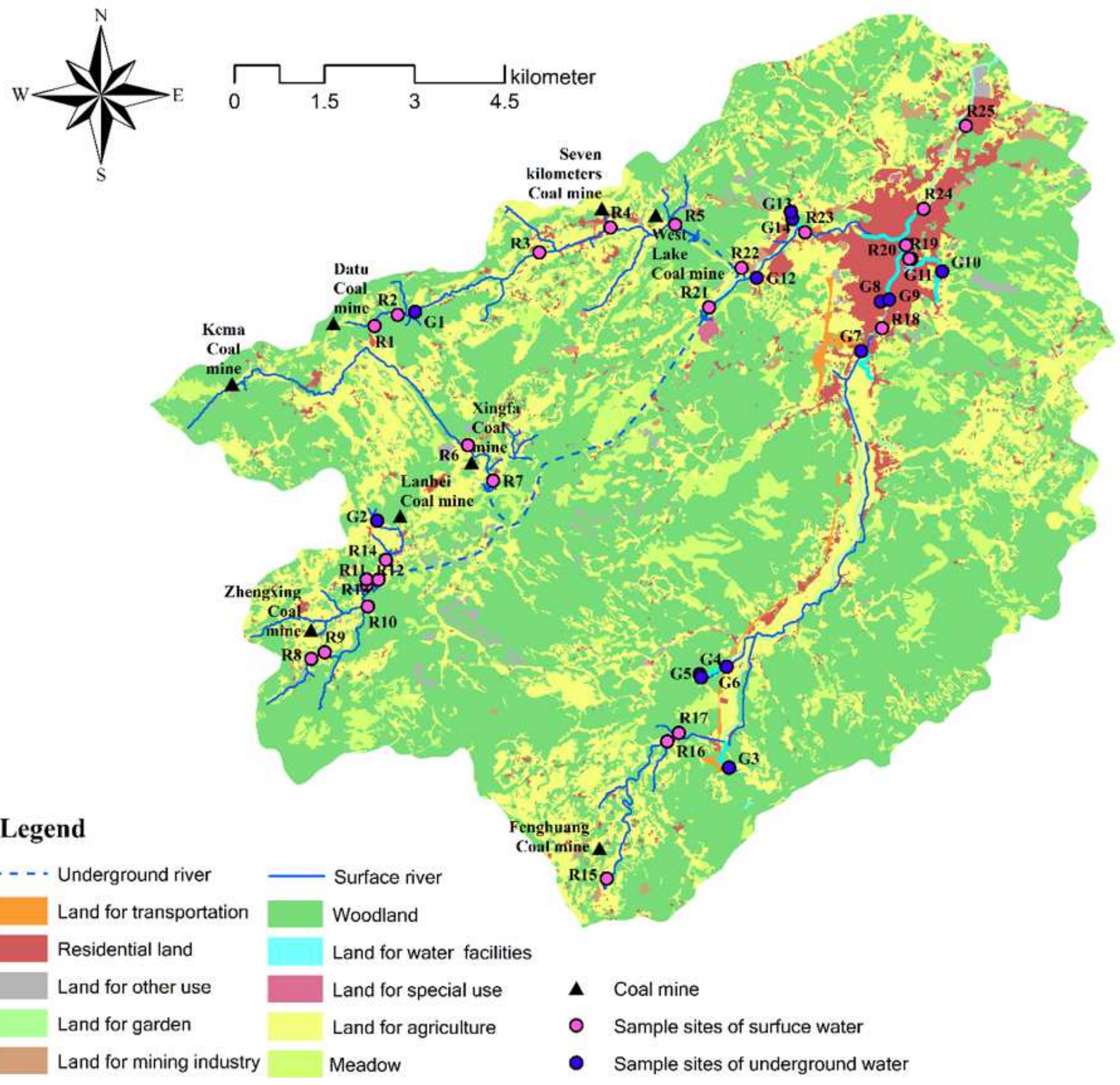

\section{Figure 1}

Sampling sites in Zhijin County, China(Li et al. 2021). Note: The designations employed and the presentation of the material on this map do not imply the expression of any opinion whatsoever on the part of Research Square concerning the legal status of any country, territory, city or area or of its authorities, or concerning the delimitation of its frontiers or boundaries. This map has been provided by the authors. 


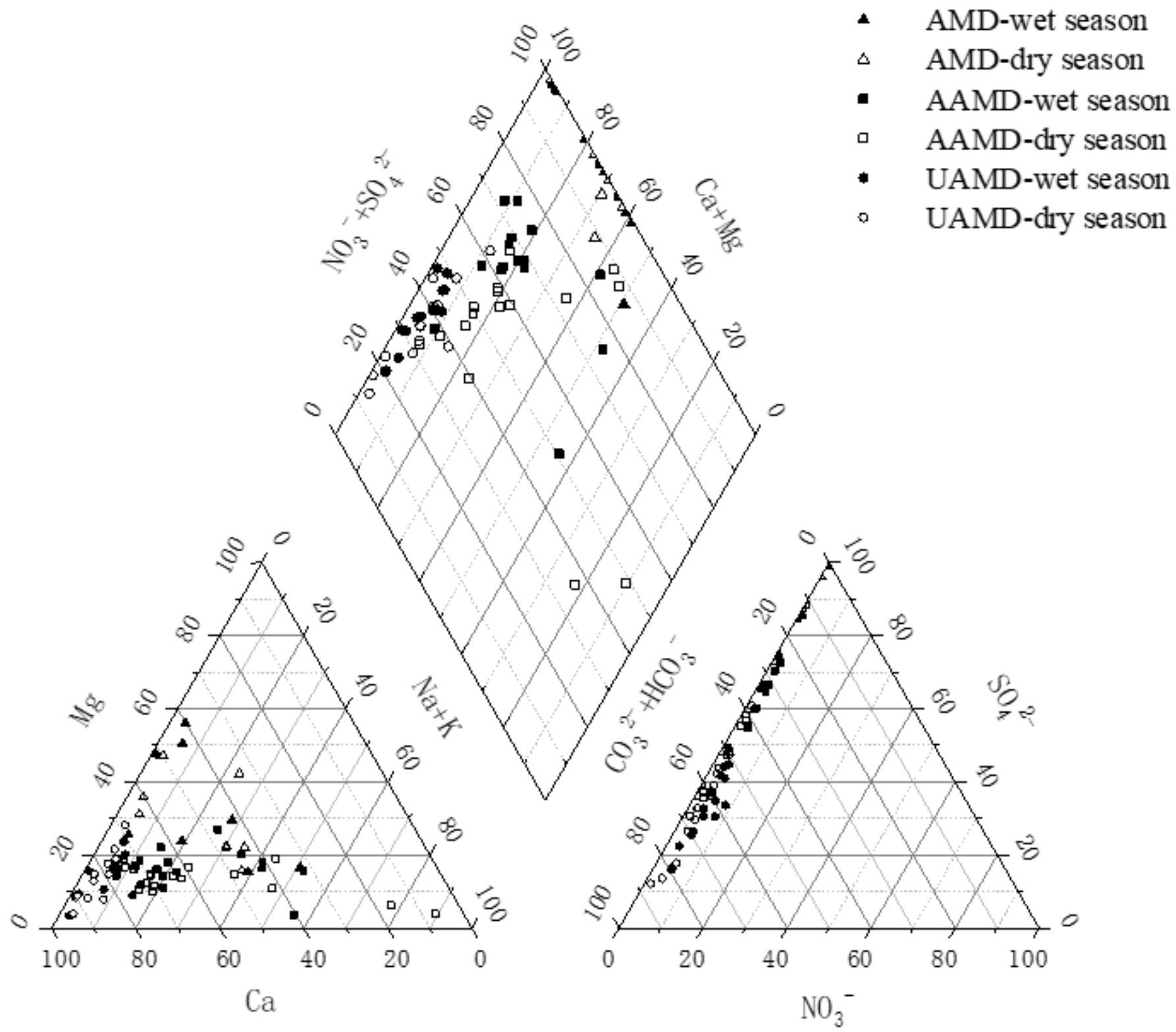

Figure 2

Piper diagram 

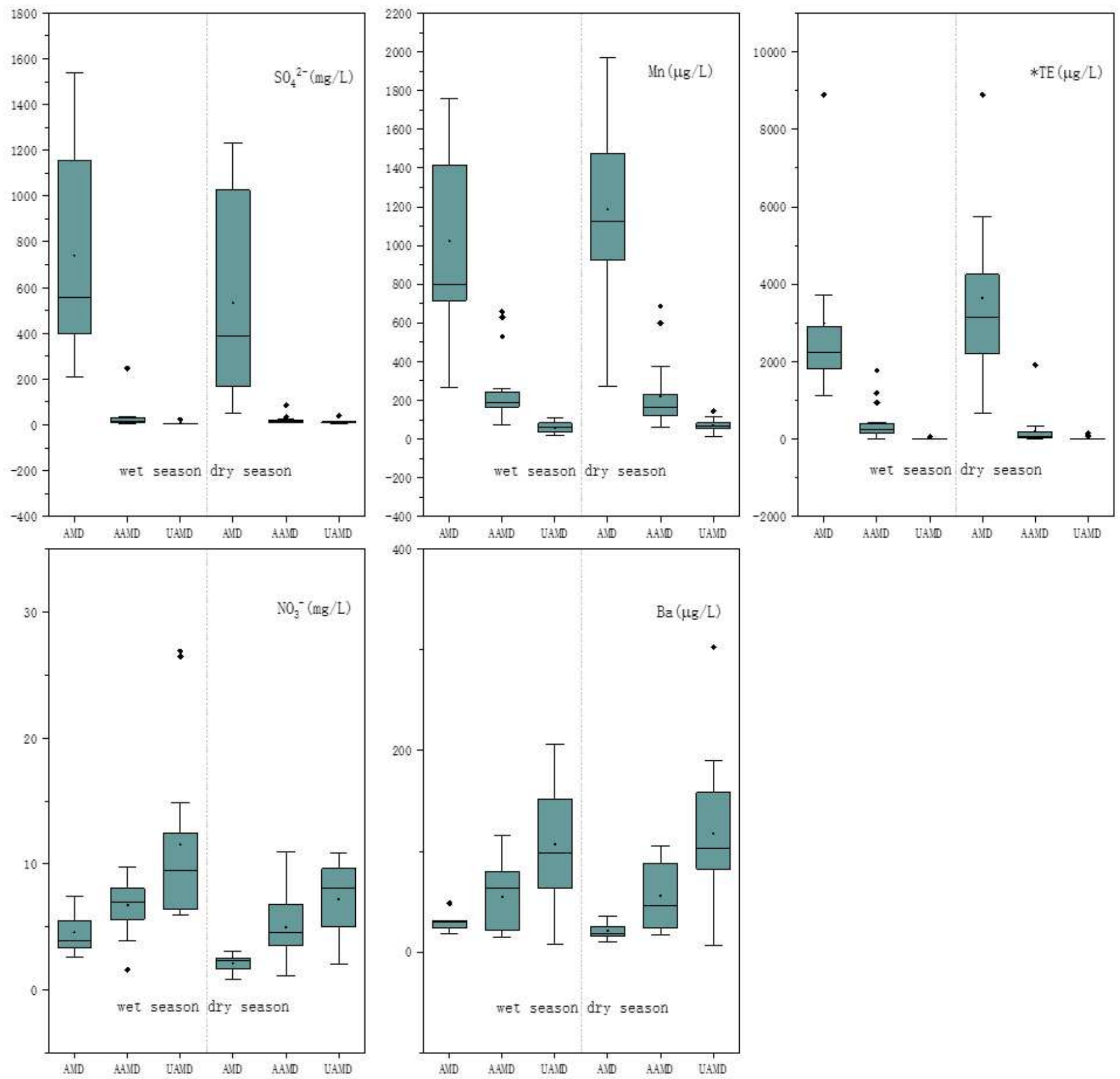

Figure 3

Boxplot of concentrations of contaminants in AMD, AAMD and UAMD *TE indicates the total concentration of $\mathrm{Cr}, \mathrm{Co}, \mathrm{Ni}, \mathrm{Cu}, \mathrm{Zn}, \mathrm{Cd}, \mathrm{Sb}, \mathrm{Pb}$ and $\mathrm{As}$ 

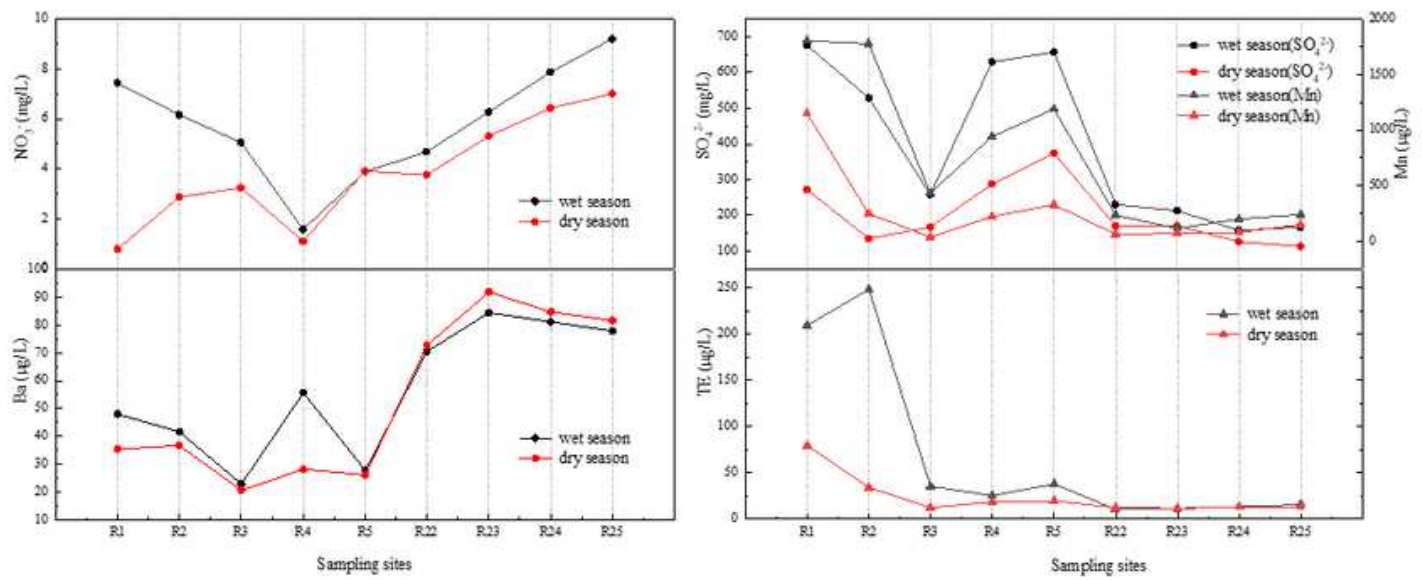

(a) Spatial-temporal variations of contaminants in Streaml
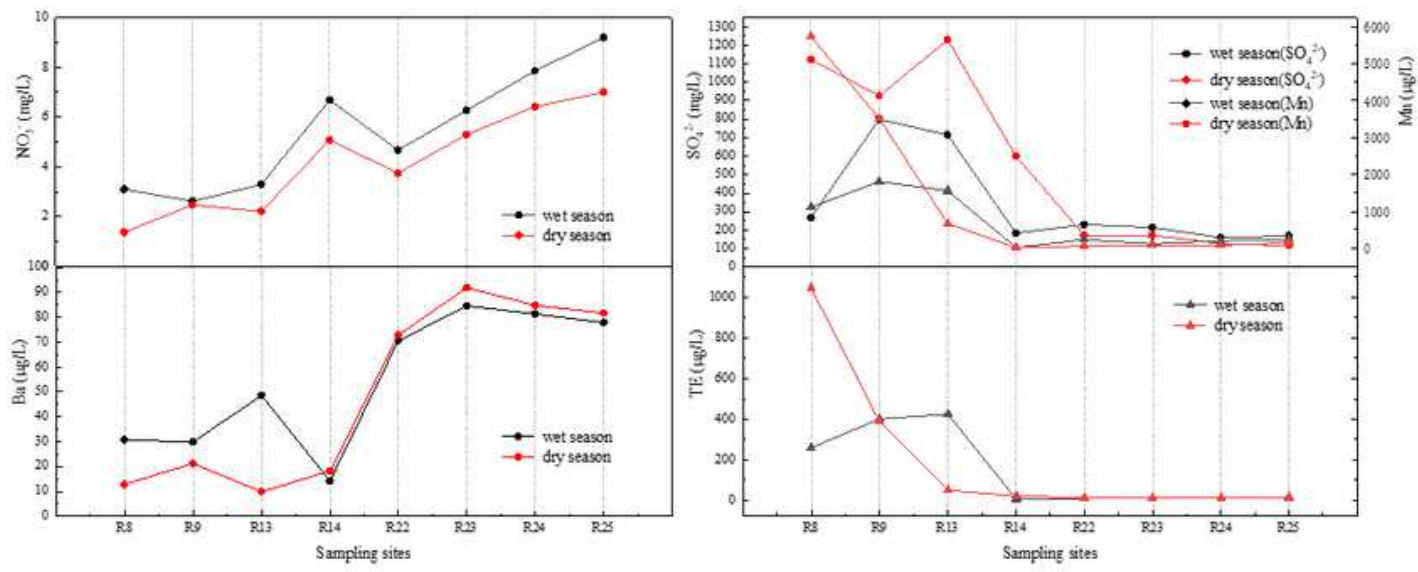

(b) Spatial-temporal variations of contaminants in Stream2
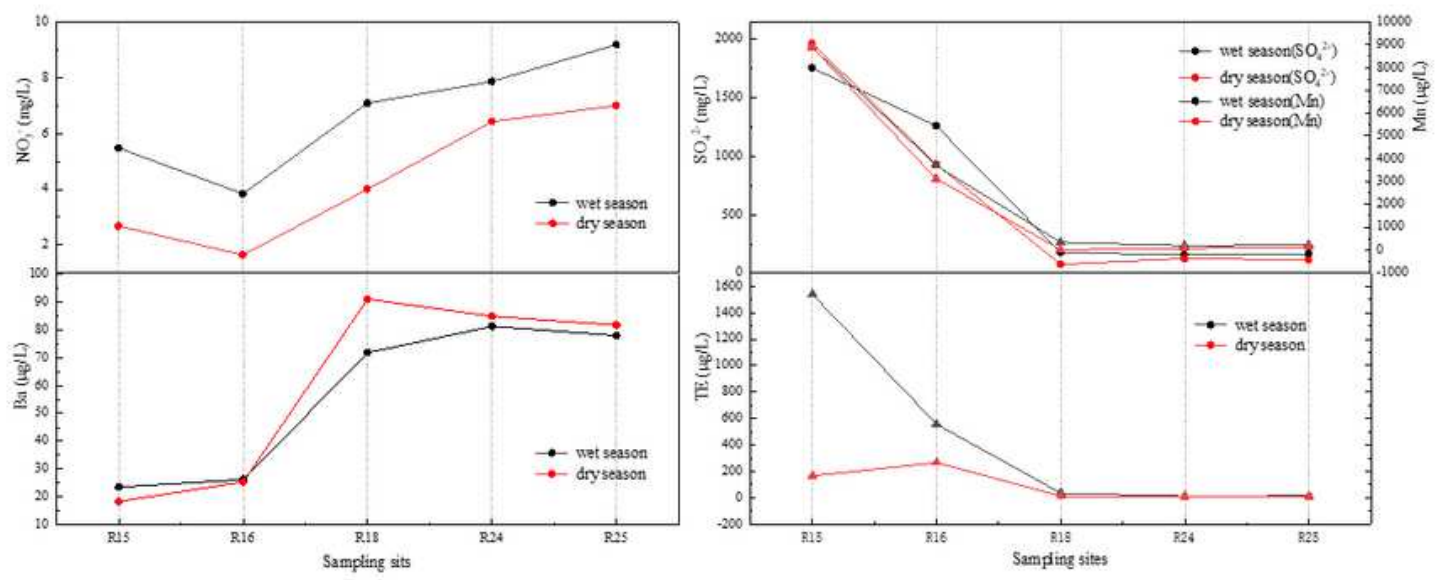

(c) Spatial-temporal variations of contaminants in Stream3

\section{Figure 4}

(a)-(c) Spatial-temporal variations of contaminants in Stream1, Stream2 and Stream3 *TE indicates the total concentration of $\mathrm{Cr}, \mathrm{Co}, \mathrm{Ni}, \mathrm{Cu}, \mathrm{Zn}, \mathrm{Cd}, \mathrm{Sb}, \mathrm{Pb}$ and $\mathrm{As}$ 


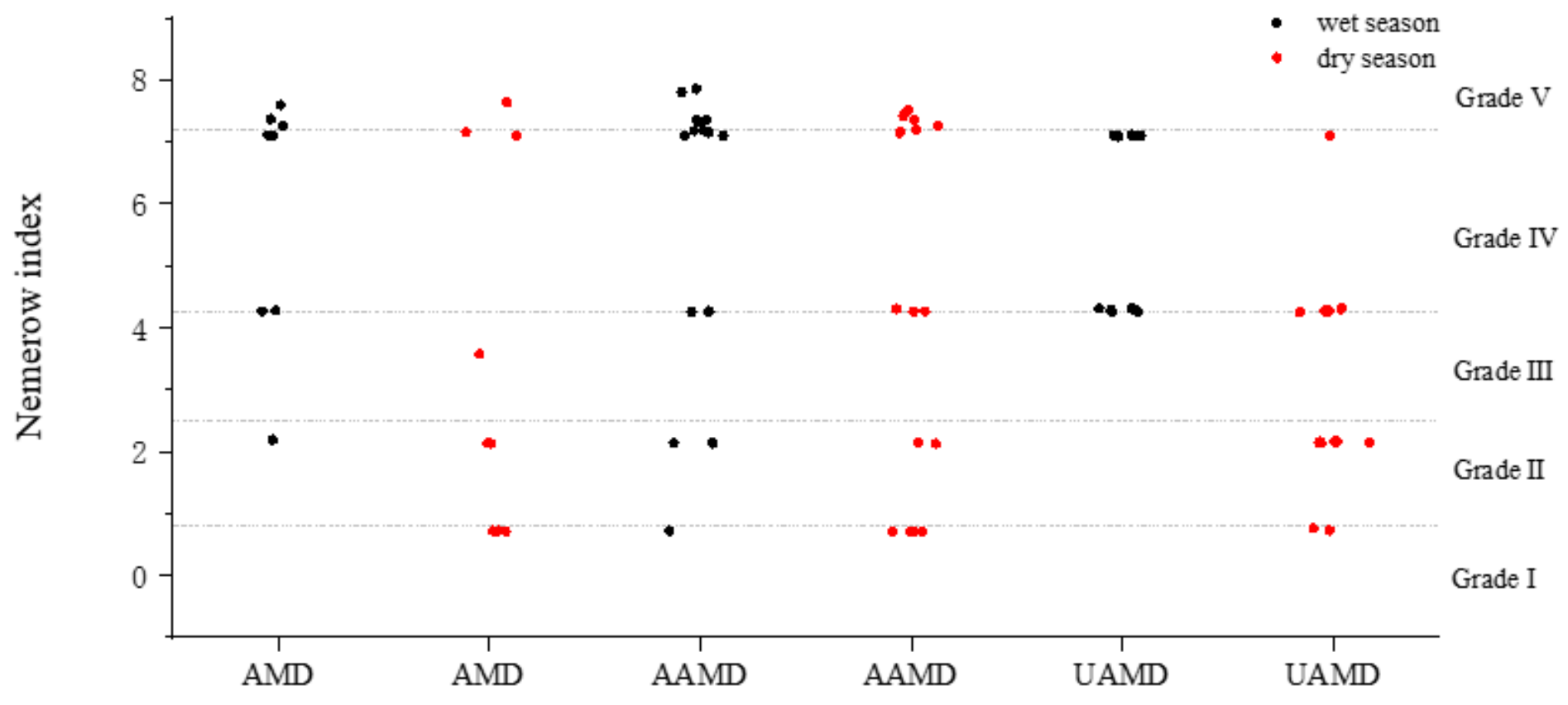

Figure 5

Results of Nemerow method 